\title{
Crustal evolution between 2.0 and 3.5 Ga in the southern Gavião block (Umburanas-Brumado-Aracatu region), São Francisco Craton, Brazil: A 3.5-3.8 Ga proto-crust in the Gavião block?
}

\author{
Marilda Santos-Pinto a , Jean-Jacques Peucat ${ }^{\mathrm{b}, *}$, Hervé Martin ${ }^{\text {c, d,e }}$, Johildo S.F. Barbosa ${ }^{\mathrm{f}}$, C. Mark Fanning ${ }^{\mathrm{g}}$, \\ Alain Cocherie $^{\mathrm{h}}$, Jean-Louis Paquette ${ }^{\mathrm{c}, \mathrm{d}, \mathrm{e}}$ \\ ${ }^{a}$ UEFS-Dep. Ciências Exatas, Av. Transnordestina, s/n Novo Horizonte, 44036-900 Feira de Santana, BA, Brazil \\ ${ }^{\mathrm{b}}$ Géosciences-Rennes, UPR 4661 CNRS, Université de Rennes I, 35042 Rennes, Cedex, France \\ ${ }^{c}$ Clermont Université, Université Blaise Pascal, Laboratoire Magmas et Volcans, BP 10448, F-63000 Clermont-Ferrand, France \\ d CNRS, UMR 6524, LMV, F-63038 Clermont-Ferrand, France \\ e IRD, R 163, LMV, F-63038 Clermont-Ferrand, France \\ ${ }^{\mathrm{f}}$ Rua Barão de Jeremoabo, s/n, Campus universitário de Ondina, 40170-020, Salvador, BA, Brazil \\ ${ }^{g}$ Research School of Earth Sciences, ANU, Canberra, Australia \\ ${ }^{\mathrm{h}}$ BRGM (ANA/ISO), 3 Avenue C. Guillemin, BP 36009, 45060 Orléans Cedex 2, France
}

\section{A R T I C L E I N F O}

\section{Article history:}

Received 11 March 2011

Accepted 19 September 2012

\section{Keywords:}

SHRIMP zircon ages

In-situ monazite ages (EPMA, LA-ICPMS)

Sm-Nd

Archean and Paleoproterozoic

Gavião block

Bahia-Brazil

\section{Introduction}

In the São Francisco Craton, the Gavião block, which recorded a crustal history up to 3.1-3.4 Ga (references in Table 1), is one of the oldest continental segments in South America. Nevertheless, this vast area has not been subjected to extensive $\mathrm{U}-\mathrm{Pb}$ in-situ zircon dating (ion probe and LA-ICPMS), with the result that its geochronological evolution is not very well constrained (Figs. 1 and 2 , Table 1). The purpose of this work is to provide new in-situ $\mathrm{U}-\mathrm{Pb}$ ages for the Gavião block and to discuss the petrogenetic and

\footnotetext{
* Corresponding author. Tel.: +332232360 85; fax: +33223236097.

E-mail addresses: mspinto@atarde.com.br (M. Santos-Pinto), peucat@univrennes1.fr (J.-J. Peucat), martin@opgc.univ-bpclermont.fr (H. Martin), johildo.barbosa@gmail.com (J.S.F. Barbosa), Prise.Fanning@anu.edu.au (C.M. Fanning), alain.cocherie@sfr.fr (A. Cocherie), paquette@opgc.univ-bpclermont.fr (J.-L. Paquette).
}

geodynamic implications of these results in order to more precisely determine the crustal evolution between 1.97 and $3.49 \mathrm{Ga}$ in this part of the São Francisco craton.

\section{Geological setting}

The basement of the São Francisco Craton, in the state of Bahia, consists of four main crustal segments: the Serrinha, Itabuna-Salvador-Curaçá, Jequié and Gavião blocks (Barbosa and Sabaté, 2002, 2004; Delgado et al., 2003 and references therein) (Fig. 1). These authors proposed that the four Archean blocks collided with each other during a Paleoproterozoic orogeny, resulting in the tectonic thrusting of the high grade Itabuna-Salvador-Curaçá block over the Jequié block, with both blocks overlapping the Gavião block (Fig. 1). This tectonic overstacking resulted in a major crustal thickening and a correlated high grade regional metamorphism between 2.0 


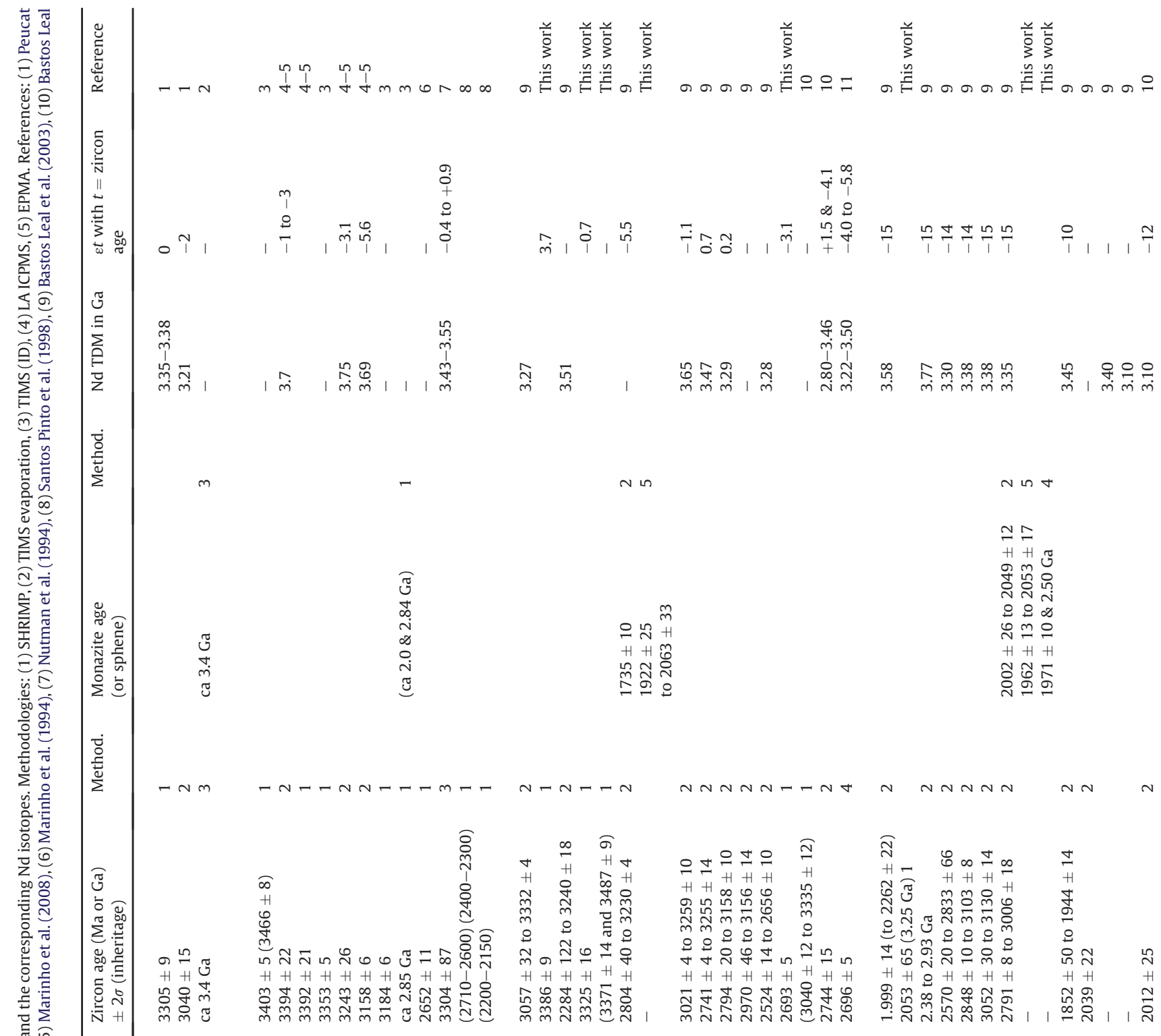

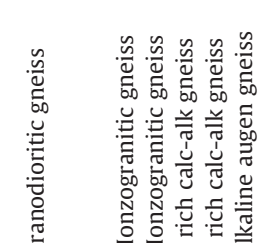

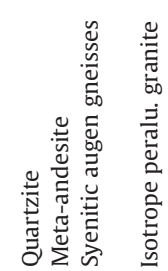

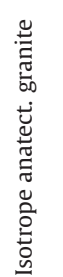

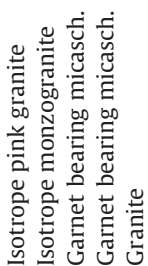
$\stackrel{\tilde{E}_{0}}{\check{E}}$

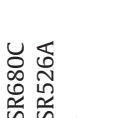

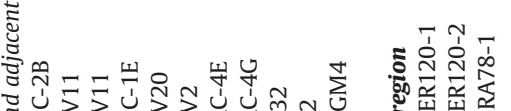

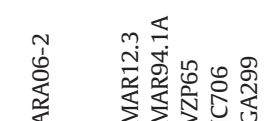

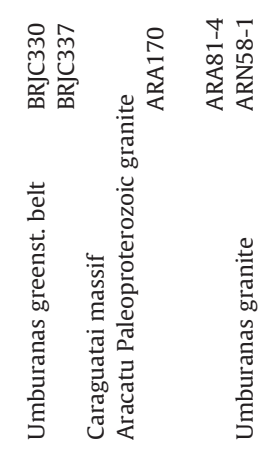

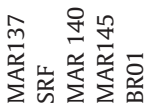


and 2.1 Ga (Barbosa and Sabaté, 2002, 2004; Delgado et al., 2003; Peucat et al., 2011).

The Gavião block (GB) mainly consists of Archean orthogneisses including TTG suites with $\mathrm{U}-\mathrm{Pb}$ zircon ages ranging from 2.8 to 3.4 Ga (Table 1 ). They were metamorphosed and partially recycled into migmatites and granites at ca 2.6-2.7 Ga (Marinho, 1991; Martin et al., 1991; Nutman and Cordani, 1993; Santos Pinto et al., 1998; Cruz et al., 2012 and references therein). Disrupted supracrustal belts, such as the Contendas-Mirante volcano-sedimentary sequence and the Umburanas and Mundo Novo greenstone belts, gave Archean zircon ages ranging between ca 2.6 and $3.3 \mathrm{Ga}$ (Marinho, 1991; Cunha and Fróes, 1994; Mascarenhas and Silva, 1994; Peucat et al., 2002). The U-Pb available ages, Sm-Nd data and related references are reported in Table 1. Pioneer work ( $\mathrm{Rb}-\mathrm{Sr}$ and $\mathrm{K}-\mathrm{Ar}$ ages) is reported in Table 1 of Cruz et al. (2012).

Paleoarchean terrains (ca 3.2-3.4 Ga, Table 1) were first recognized in the Sete Voltas and Boa-Vista/Mata Verde massifs, in the Contendas-Mirante region, which are all located on the southeastern margin of the Gavião block (Martin et al., 1991, 1997; Nutman and Cordani,1993). Felsic volcanics of the lower sequence of the Contendas-Mirante belt provided a TIMS zircon age of ca $3.30 \mathrm{Ga}$ (Marinho, 1991, 1994). In gneisses from the western side of the Mundo-Novo belt (Fig. 1) in northern Gavião, Mougeot (1996) also obtained TIMS zircon ages ca $3.4 \mathrm{Ga}$. In a recent work, Dantas et al., 2010, reported a zircon age ca 3.5 Ga for a gneiss of the northern side of the São Francisco craton, close to Petrolina (Pernambuco).

In the studied Umburanas-Brumado-Aracatu region (UBA) (Fig. 2), several orthogneissic units crop out (Bernada, Aracatu, Eixo and Mariana massifs, Fig. 2) which have various sources and contrasted petrogenesis (Santos Pinto, 1996), their zircon evaporation ages range from the Paleo- to the Mesoarchean (Table 1). They are in tectonic contact with the Neoarchean Umburanas greenstone belt (Cunha and Fróes, 1994; Bastos Leal et al., 2003). Locally, the gneisses appear to be strongly metamorphosed during the Paleoproterozoic event at ca $2.0 \mathrm{Ga}$. A short description of the main gneissic units is presented here and their geochemistry is summarized in Table 2. More details (petrography and geochemistry) are available in Santos-Pinto (1996) and Santos Pinto et al. (1998).

The Bernada gneissic Massif is a composite body made up of three main granodioritic to tonalitic Paleoarchean orthogneisses (Tables 1 and 2). The main mineralogy is composed of plagioclase $\mathrm{An}_{24-32}$ (45-50\%), quartz (30-35\%), K-feldspar (7-20\%) and biotite (1-9\%); the accessory phases include apatite, opaque minerals, sphene and zircon. The secondary minerals are epidote, sericite and carbonate. The granodiorites systematically have a $\mathrm{K}_{2} \mathrm{O} / \mathrm{Na}_{2} \mathrm{O}$ ratio $>1$, such that they belong to a high-K calc-alkaline suite and have a similar composition to the granite-granodiorite limit, whereas the tonalites are characterized by $\mathrm{K}_{2} \mathrm{O} / \mathrm{Na}_{2} \mathrm{O}=0.4$. There are no available REE data on this suite.

The Aracatu Massif consists of two main Paleoarchean lithologies: granodioritic to trondhjemitic gray gneisses and granitic gneisses that display a strong foliation. Locally, these gneisses are intensively migmatized, such that they can appear as relicts or boudins in diatexitic migmatites to the SW of the town of Aracatu (Fig. 3). The trondhjemitic gneisses contain plagioclase $\mathrm{An}_{23-34}$ (45-55\%), quartz (30-35\%), K-feldspar (1-6\%) and biotite (5-15\%); the accessory phases are apatite, opaque minerals, sphene and zircon, while the secondary phases are epidote, sericite and carbonate. They possess typical TTG fractionated REE patterns: high light REE contents $\left(\mathrm{La}_{N}=80-170\right)$ and very low heavy REE contents $\left(\mathrm{Yb}_{N}=1-4\right)$, with slightly negative Eu anomalies $\left(\mathrm{Eu}^{*} / \mathrm{Eu}=0.57-\right.$ 0.70). Quantitative geochemical modeling indicated that the trondhjemite could result from 65 to $80 \%$ degree of partial melting of the old Sete Voltas-like gray gneisses (Martin et al., 1991) or alternatively, that they would be derived from the partial melting of 


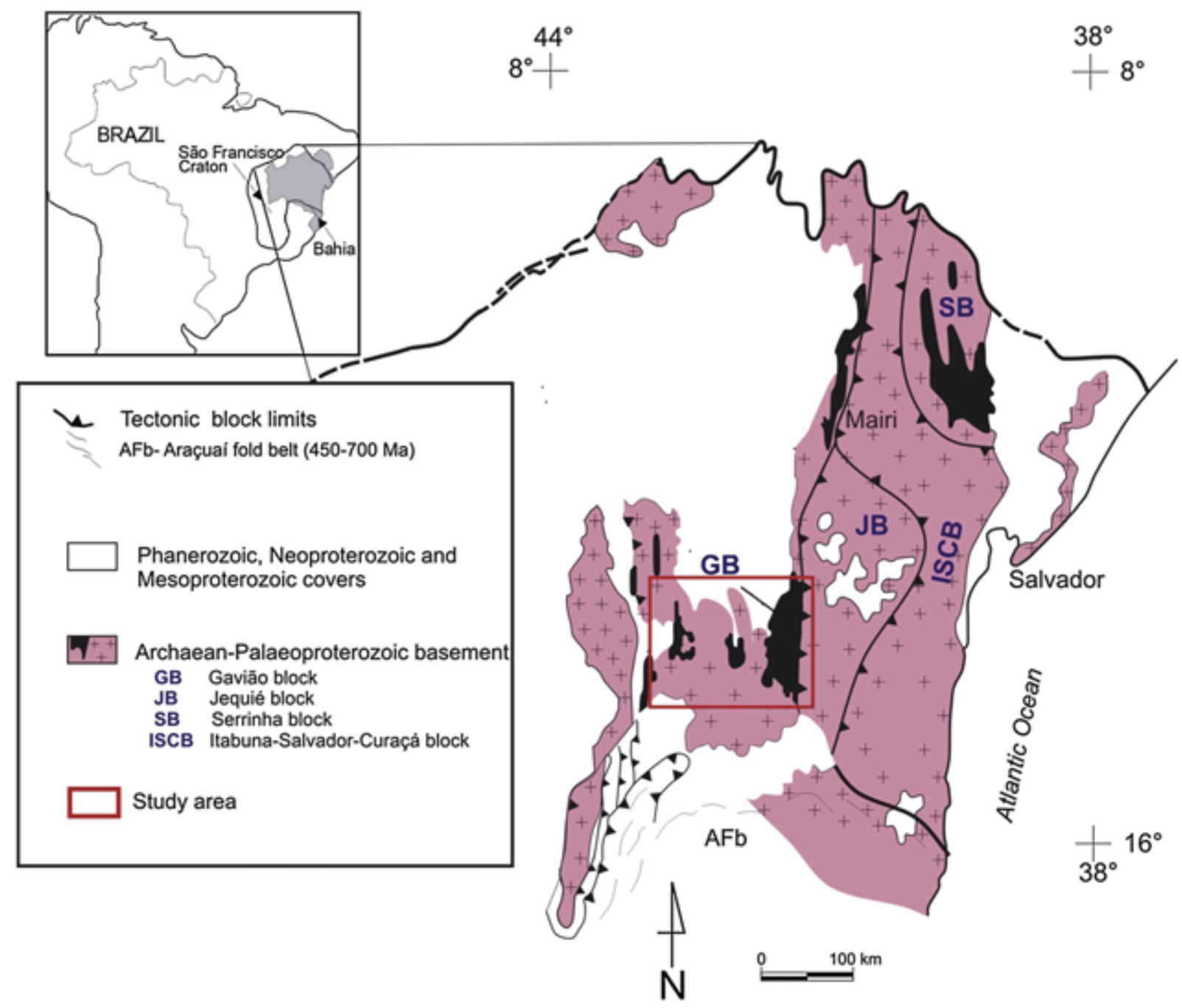

Fig. 1. Schematic geological map showing the limits, marginal fold belts and major structural units of the São Francisco Craton. GB - Gavião Block; JB - Jequié Block; SB - Serrinha Block; ISCB - Itabuna-Salvador-Curaçá Block. The rectangle indicates the studied area (adapted from Alkmim et al., 1993).

an Enriched Archean Tholeiite (EAT; Condie, 1981) that was previously contaminated by huge amounts of the old Sete Voltas gneisstype. Located south of Aracatu (Fig. 2), the Mariana gneisses have a granitic K-rich calc-alkaline composition with predominant $\mathrm{K}_{2} \mathrm{O} /$ $\mathrm{Na}_{2} \mathrm{O}$ ratios $\geq 1$. They have the same zircon ages as the Aracatu trondhjemitic gneisses (up to 3.26 Ga; Table 1 ), with Nd model ages up to $3.6 \mathrm{Ga}$, which were interpreted as indicative of general crustal reworking processes in this area (Santos Pinto et al., 1998).

The Serra do Eixo Massif, to the north of Aracatu, is composed of two main gneissic units:

(1) - a K-rich calc-alkaline Mesoarchean augen-gneiss of monzogranitic composition, $\mathrm{K}_{2} \mathrm{O} / \mathrm{Na}_{2} \mathrm{O}$ ratio $\leq 1$, zircon evaporation ages ranging from 2.80 to $3.16 \mathrm{Ga}$ with $\mathrm{Nd}$ model ages ca $3.3 \mathrm{Ga}$, (Tables 1 and 2). (2) - an alkaline Neoarchean granitic gneiss, which also appears as a K-feldspar augen-gneiss. It is composed of K-feldspar (by up to $43 \%$ ), plagioclase (18-23\%) and biotite $(<4 \%)$. The alkaline affinity is also shown by a $\mathrm{K}_{2} \mathrm{O} / \mathrm{Na}_{2} \mathrm{O}$ ratio $>1$ and $\left(\mathrm{Al}_{2} \mathrm{O}_{3}+\mathrm{CaO}\right) /$ $\left(\mathrm{FeO}_{t}+\mathrm{Na}_{2} \mathrm{O}+\mathrm{K}_{2} \mathrm{O}\right)<1.4$ (Sylvester, 1989). They are very rich in $\operatorname{LREE}\left(\operatorname{La}_{N}=114-263\right)$ and have high HREE contents $\left(\mathrm{Yb}_{N}\right.$ up to 25$)$, which results in poorly fractionated patterns with $\mathrm{La} / \mathrm{Yb}_{(N)}=10$. In addition, they display pronounced negative Eu anomalies (Eu/ $\mathrm{Eu}^{*}=0.40-0.55$ ). This composition is similar to that of the ALK-3 type of Archean alkaline granites described in Sylvester (1994).
They are interpreted as having been generated by $60 \%$ melting of the surrounding Mesoarchean high-K calc-alkaline augen-gneisses.

Two Paleoproterozoic granite massifs in the UmburanasBrumado-Aracatu region (Fig. 2, Table 1) have been investigated. (1) The Umburanas Massif is a peraluminous biotite-muscovite granite with monazite, normative corundum $>1 \%$ and zircon with a morphology that is typical of S-type granites (Pupin, 1980). It shows low REE content with $\mathrm{La}_{N}=69-74$ and $\mathrm{Yb}_{N}=2.3-3$, with a small negative Eu anomaly $\left(\mathrm{Eu} / \mathrm{Eu}^{*}=0.70\right)$. The TIMS evaporation zircon ages range from 2.57 to $3.13 \mathrm{Ga}$, while the monazite ages range between $2002 \pm 26$ and $2049 \pm 12$ Ma. Geochemical modeling shows that this granite can be generated by $25 \%$ melting of the surrounding gneisses. (2) The Aracatu calc-alkaline granite (too small to be reported in Fig. 2) is a syeno- to monzogranite composed of plagioclase $\mathrm{An}_{25-29}(15-37 \%)$, quartz (37-40\%), microcline $(23-48 \%)$ and biotite $(<2.5 \%)$. The accessory phases are opaque minerals, sphene, apatite, zircon. Locally, this granite contains migmatitic and gneissic enclaves and schlieriens. The REE patterns show $\mathrm{La}_{N}=47-61, \mathrm{Yb}_{N}=2.3-10,(\mathrm{La} / \mathrm{Yb}) N=4.7-21.7$ and negative Eu anomalies $\left(\mathrm{Eu} / \mathrm{Eu}^{*}=0.64-0.73\right)$. The single zircon ages lie between 1.95 and $2.26 \mathrm{Ga}$. Geochemical modeling suggests that it could be generated by $50 \%$ melting of the surrounding Aracatu Archean gray gneisses. 


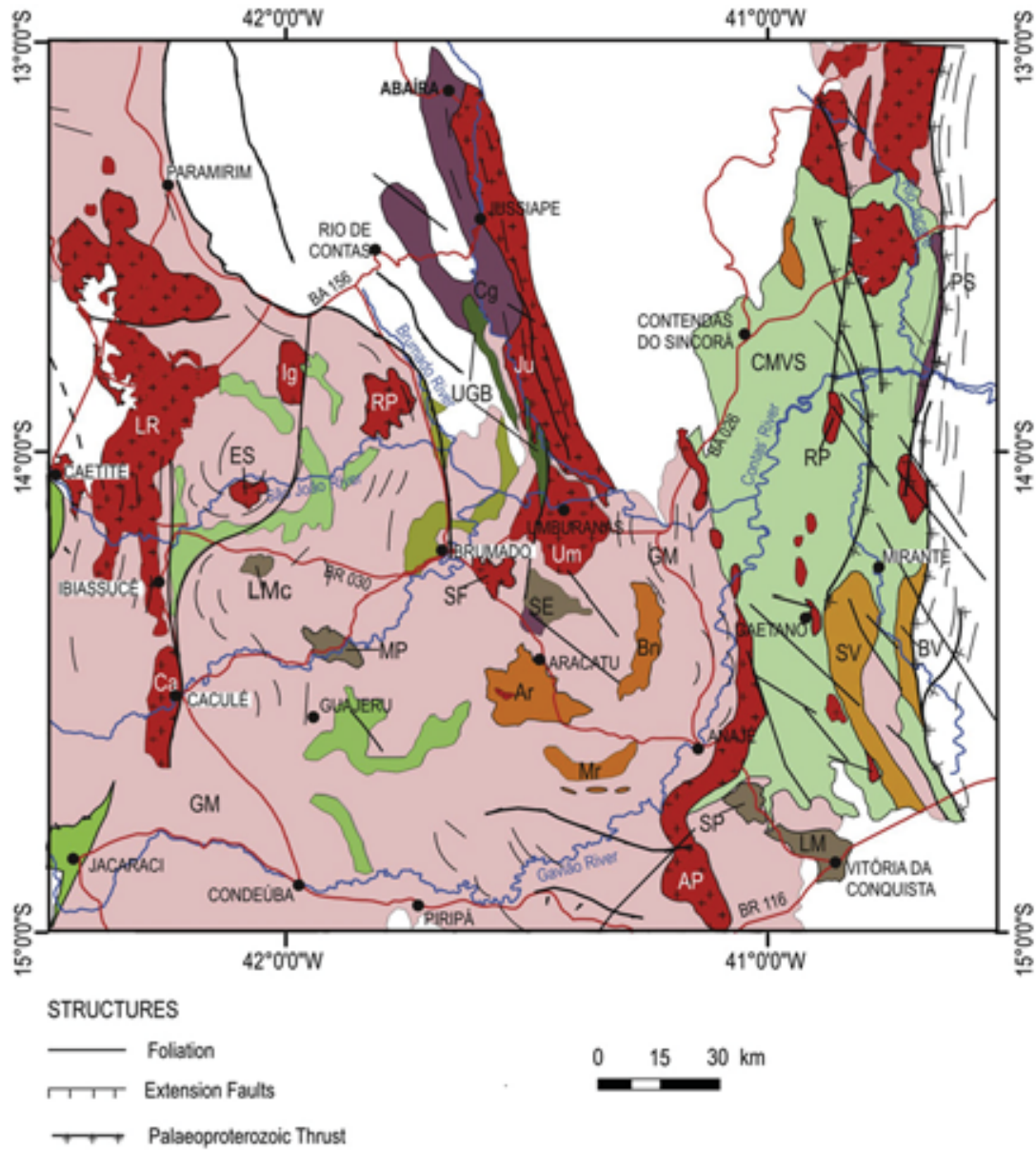

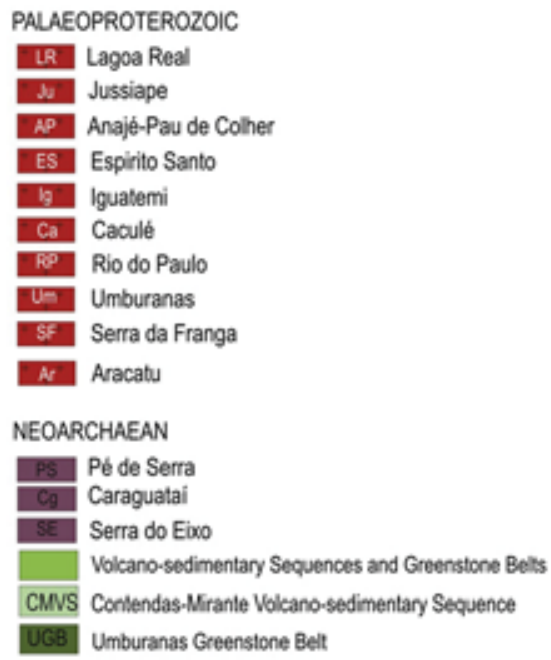

MESOARCHAEAN

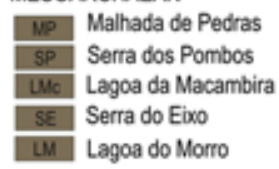

PALAEOARCHAEAN

\begin{tabular}{|l|l|}
\hline Mr & Mariana \\
\hline Av & Aracatu \\
\hline Bn & Bernada \\
\hline BV & Boa Vista/Mata Verde \\
\hline SV & Sete Voltas \\
\hline GM & Gneisses and Migmatites \\
\hline
\end{tabular}

Fig. 2. Simplified geological map of the studied area (modified after Santos Pinto, 1996). White zones correspond to Proterozoic and Cenozoic covers and all the green areas to various greenstone belts. (For interpretation of the references to colour in this figure legend, the reader is referred to the web version of this article.)

Neoproterozoic Brazilian events are also recorded in the Gavião block with the $\mathrm{Rb}-\mathrm{Sr}$ biotite-whole rock isochrons giving a $533 \pm 11$ Ma cooling age in the Serra do Eixo Massif and $508 \pm 10$ Ma in the Aracatu Massif (Santos Pinto et al., 1998). Similarly, Paleozoic ages were obtained by $\mathrm{K}-\mathrm{Ar}$ dating in the Paleoproterozoic Rio do Paulo (507 $\pm 6 \mathrm{Ma}$ ), Espírito Santo (490 $\pm 12 \mathrm{Ma}$ ) and Iguatemi (483 $\pm 5 \mathrm{Ma}$ ) granitic massifs (Bastos Leal et al., 2000).

\section{New $\mathrm{U}-\mathrm{Pb}$ results on zircon and monazite}

During this work, we obtained four new SHRIMP U-Pb zircon dates. The ages are ${ }^{207} \mathrm{~Pb} /{ }^{206} \mathrm{~Pb}$ weighted averages of the concordant to sub-concordant analyses. They are given at $\pm 2 \sigma$, using the Isoplot program (Ludwig, 2003, Table 3). In addition, we performed three in-situ $\mathrm{U}-\mathrm{Pb}-\mathrm{Th}$ analyses on the monazites (Aracatu gray-gneiss and Umburanas granite) using the EPMA and/or LA-ICPMS methods in order to better constrain the Paleoproterozoic evolution.

\subsection{Zircon from a tonalitic gneiss of the Bernada Massif (sample BER-120.1)}

The zircon grains are euhedral and belong to the S25 high temperature type described in Pupin (1980). They are strongly zoned as is the growth of zircon in a magmatic environment (Fig. 4). Seven analyses (out of twelve) are concordant to sub-concordant and define a weighted ${ }^{207} \mathrm{~Pb} /{ }^{206} \mathrm{~Pb}$ average of $3386 \pm 9 \mathrm{Ma}$ $(\mathrm{MSWD}=2.5)$; this is interpreted as the age of the tonalitic precursor.
3.2. Zircon and monazite from trondhjemitic gray gneisses of the Aracatu Massif (samples ARA-78.1 and ARA-06.2)

The zircon grains are euhedral and belong to the S9, S13 and S18 crustal types described by Pupin (1980) (Fig. 5; Table 3). The images show complex structures with cores and overgrowths, both of which are strongly zoned. The youngest set of concordant to slightly discordant zoned overgrowths (i.e. gr. 8; Fig. 5) define $\mathrm{a}^{207} \mathrm{~Pb} /{ }^{206} \mathrm{~Pb}$ average age of $3325 \pm 16 \mathrm{Ma}(\mathrm{MSWD}=2.6)$ which is interpreted as the age of the magmatic precursor of the gneiss. A set of five cores (i.e. gr. 10; Fig. 4) exhibits a mean ${ }^{207} \mathrm{~Pb} /{ }^{206} \mathrm{~Pb}$ age of $3366 \pm 15 \mathrm{Ma}(\mathrm{MSWD}=2.9)$ and one other concordant core defines an age of $3487 \pm 9$ Ma (Fig. 5). These ages are interpreted as evidence of an inherited older crustal component in the granitic melt that emplaced at $3325 \pm 16$ Ma.

A Paleoproterozoic event is recorded in a second sample of these trondhjemitic gneisses (ARA-06.2, Table 1). One monazite that grew around an apatite crystal has been dated using the EPMA method. Based on a set of 200 analyses, a large range of ages is observed between $800 \mathrm{Ma}$ and $2100 \mathrm{Ma}$, indicating significant lead loss in this grain (the figure is not included here). A set of 43 analyses provides an age of $1922 \pm 25$ Ma. The high MSWD (3.4) shows that this dataset cannot be considered as a single age population (Fig. 6a). Finally, a limited domain exhibits a population of the nine oldest analyses producing a homogeneous result of $2063 \pm 33 \mathrm{Ma}$ (Fig. 6b). In Fig. 6b, the error ellipses define the bestfit line (regression line), which is quite close to the theoretical 


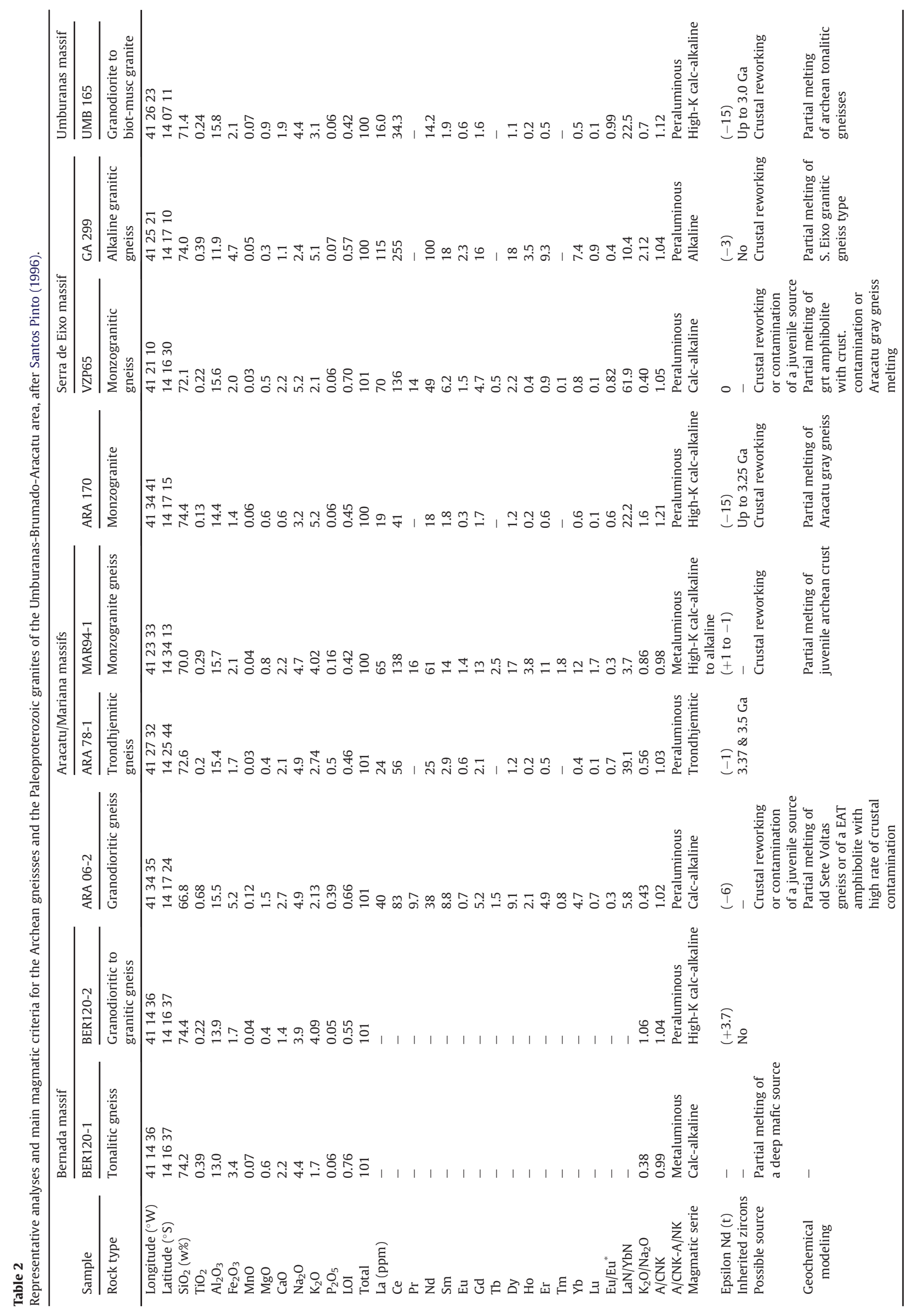




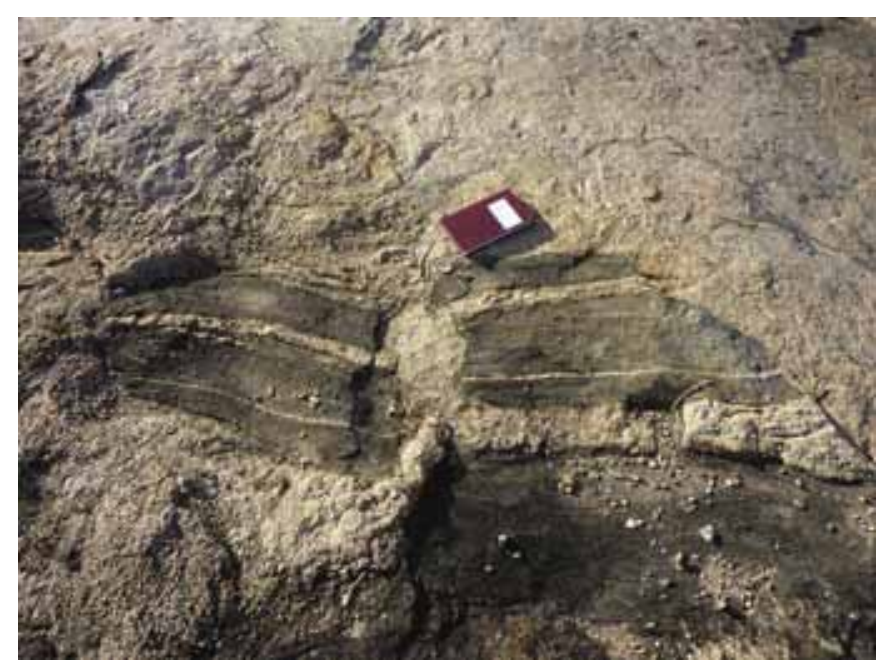

Fig. 3. Relics of Archean boudined gneisses within diatexitic Paleoproterozoic migmatites, close to the town of Aracatu.

isochron, and makes the mean age of $2063 \mathrm{Ma}$, calculated at the centroid of the population significant (Cocherie and Albarède, 2001). These data demonstrate the Paleoproterozoic age for the crystallization of monazite, disrupted by the partial opening of the $\mathrm{U}-\mathrm{Th}-\mathrm{Pb}$ system up to $800 \mathrm{Ma}$.

\subsection{Zircon from the alkaline granitic gneiss of the Serra de Eixo (sample GA-299)}

Zircon grains are euhedral, strongly zoned magmatic grains and have a typical high temperature alkaline morphology (types S24 and S25 in Pupin, 1980, Fig. 7 and Table 3). The major set (13/15) of data is concordant to sub-concordant and defines a weighted average of ${ }^{207} \mathrm{~Pb} /{ }^{206} \mathrm{~Pb}$ ages at $2693 \pm 5 \mathrm{Ma}(\mathrm{MSWD}=0.98)$, which is interpreted as the age of the alkaline magmatic protolith.

\subsection{Zircon from the Aracatu granite (sample ARA-170)}

Zircon grains are euhedral, brown, with a high $U$ content and are partially or totally metamict; nevertheless, some cores and overgrowths were preserved (Fig. 8; Table 3). They belong to the S4, S5 and S9 types described in Pupin (1980), which this author considered as characteristic of anatectic granites. Despite a careful selection of the analysis sites, several grains have a high common lead content and are strongly discordant, resulting in high errors on the ages (spots 1.2 and 3.1; Table 2). The core of grain 1 is slightly discordant and gives a ${ }^{207} \mathrm{~Pb} /{ }^{206} \mathrm{~Pb}$ age of $3245 \pm 25 \mathrm{Ma}$ (spot 1.1), which fixes a minimum age for the inheritance from the Archean gneissic source. Grain 2 is an overgrowth with a relatively low common lead content (Table 3 ); it is discordant (13\%) and has $\mathrm{a}^{207} \mathrm{~Pb} /{ }^{206} \mathrm{~Pb}$ age of $2036 \pm 19 \mathrm{Ma}$ (Table 1 ). The entire dataset for the overgrowths defines an inaccurate discordia intercept at $2058 \pm 89$ Ma which nevertheless records the Paleoproterozoic history of this granite.

\subsection{Monazite from the Umburanas biotite-rich granite}

Monazite ages were obtained using the EPMA and LA-ICPMS methods. The monazite grains are anhedral and more or less round, with limited zoning when observed in back-scattered (BS) images (Fig. 10). Some inclusions, probably of thorite, are visible (white zones in grain 1). The whole set of EPMA ages (170 analyses) obtained from nine monazite grains provides a weighted average of
$1962 \pm 13 \mathrm{Ma}($ MSWD $=1.5)$ (Fig. 9a). A set of 33 analyses, that is significantly older than the previous set, defines an isochron age of $2053 \pm 17 \mathrm{Ma}$ (MSWD =1.2; Fig. 9b). This age is similar to the oldest one obtained by TIMS from the same sample $(2049 \pm 12 \mathrm{Ma}$; Table 1$)$. In order to try to understand the range of ages observed (ca $90 \mathrm{Ma}$ ) in this sample, four of the monazite crystals were analyzed by the LA-ICPMS isotopic method (Table 4). A set of 30 analyses is concordant to slightly discordant and provides a mean ${ }^{207} \mathrm{~Pb} /{ }^{206} \mathrm{~Pb}$ age of $1971 \pm 10 \mathrm{Ma}(\mathrm{MSWD}=0.98)$. Two analyses are discordant and significantly older: spot $(9.8)$ with a ${ }^{207} \mathrm{~Pb} /{ }^{206} \mathrm{~Pb}$ minimum age of $2200 \pm 50 \mathrm{Ma}$ and spot (5.7) at $2492 \pm 70 \mathrm{Ma}$. They indicate the presence of inherited zones in the monazite grains, even if no specific structure was visible on the BS images (Fig. 10). These inherited zones could also account for some older ages (ca $2.05 \mathrm{Ga}$ ) obtained by the EPMA \& TIMS evaporation methods. Consequently, the set of youngest ages obtained by (1) TIMS at $2002 \pm 26 \mathrm{Ma}$, (2) the whole set of EPMA ages at $1962 \pm 13 \mathrm{Ma}$, and (3) the LA-ICPMS method at $1971 \pm 10 \mathrm{Ma}$, are probably the most significant; the latter age is retained as the age of the anatectic Umburanas granite.

\section{Discussion}

As expected, in terrains that underwent multiple tectonometamorphic events, the SHRIMP zircon ages are significantly older than the TIMS evaporation single zircon ages. During this work, we observed that the range of TIMS ages is broadly underestimated by approximately $1.0-2.8 \%$ compared to the SHRIMP ages. On the other hand, this work allowed to define three major Paleo- and Neoarchean magmatic events in the gneisses of the UBA region at ca $3.4,3.3$ and $2.7 \mathrm{Ga}$ and to recognize the existence of a proto-crust up to $3.5 \mathrm{Ga}$.

\subsection{The Paleoarchean events}

These events might be correlated with those evidenced in the Contendas-Mirante gneisses (Table 1). The $3386 \pm 9$ Ma plutonic age of the Bernada gray gneiss is the same as that of the Sete Voltas "old gneisses" dated by SHRIMP at $3403 \pm 5$ and $3392 \pm 21 \mathrm{Ma}$ (Table 1 and references therein). Both series have been interpreted as TTG suites derived from the partial melting of a mafic source leaving a garnet-bearing residue, which accounts for the low HREE content and the strong fractionated REE patterns (Martin et al., 1997). Consequently, both the Bernada gray gneisses and Sete Voltas old gneisses are considered as a juvenile input to the Archean continental crust that took place ca $3.4 \mathrm{Ga}$ ago. The positive $\varepsilon_{\mathrm{Nd}}$ value ( +3.7 at $3386 \mathrm{Ma}$; Tables 1 and 2 and No. 2 in Fig. 11) for the Bernada gneisses is in good agreement with a juvenile origin from a depleted mantle at ca $3.4 \mathrm{Ga}$. This is the most positive $\varepsilon_{\mathrm{Nd}}$ value ever obtained for gneisses of the Gavião block. It constitutes important evidence of the existence of a depleted mantle in this region during the Paleoarchean. By contrast, the old Sete Voltas gneisses exhibit negative $\varepsilon_{\mathrm{Nd}}$ values (between -1 and -3 at $3.4 \mathrm{Ga}$; Martin et al., 1997- No. 1 in Fig. 11), suggesting that these rocks contain an older crustal component. This is constrained by the presence of a concordant inherited zircon core dated at $3466 \pm 8$ Ma by Nutman and Cordani (1993).

The Aracatu gray gneisses give a significantly younger age at $3325 \pm 16 \mathrm{Ma}$ (No. 3 in Fig. 11), which could probably be correlated with the $3353 \pm 5 \mathrm{Ma}$ age of the Boa Vista/Mata Verde gneisses (Nutman and Cordani, 1993). These ages are also in the range of the ca $3.30 \mathrm{Ga}$ age of the Lagoa da Macambira gneisses dated by Bastos Leal et al. (1998) in the adjacent Brumado-Caculé-Caetité region. The Aracatu gray gneisses have a negative $\varepsilon_{\mathrm{Nd}}$ value $(-1$ at $3325 \mathrm{Ma}$ ) and contain inherited zircon cores dated at $3371 \pm 14 \mathrm{Ma}$, 


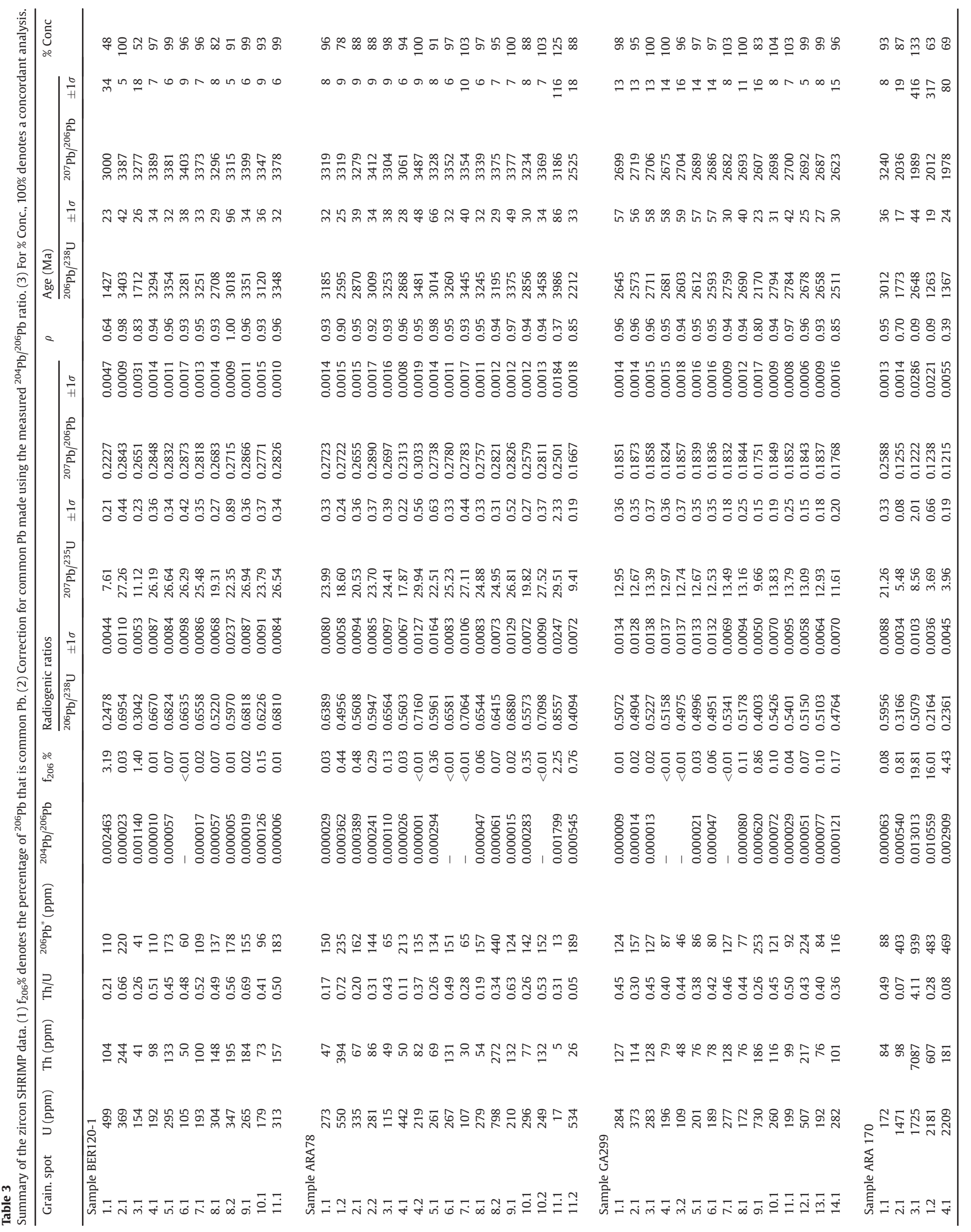




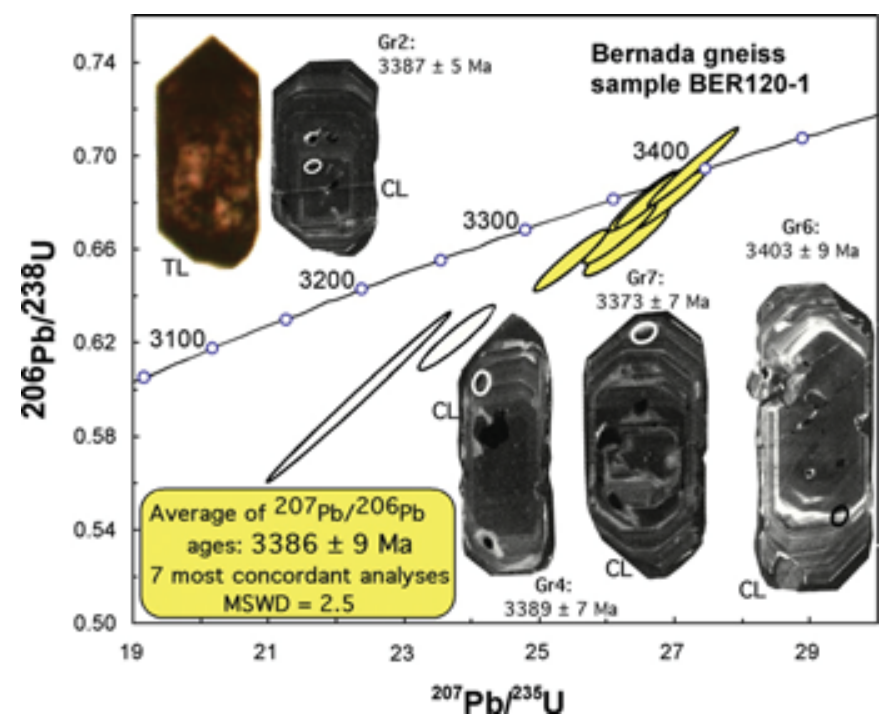

Fig. 4. Concordia diagram with cathodo-luminescence (CL) and transmitted light (TL) images for magmatic zircon grains of a trondhjemitic gneiss from the Bernada Massif (sample BER120-1). SHRIMP analyses and error ellipses are reported at $1 \sigma$. The spot size reported is around $30 \mu \mathrm{m}$.

which are within the time range obtained for the emplacement of the Bernada gneiss (3386 $\pm 9 \mathrm{Ma})$. Moreover, these results are in agreement with the geochemical modeling carried out by Santos Pinto (1996) which showed that the Aracatu trondhjemite could have been generated by a high degree of melting of the old Sete Voltas gray gneiss-type (Table 2). The $3487 \pm 9$ Ma age measured on one zircon core from the Aracatu gneisses is one of the oldest age reported in the Gavião block so far; it is a new evidence of the occurrence of a $\sim 3.5 \mathrm{Ga}$ old proto-crust in this region.

\subsection{The existence of a Neoarchean magmatism in the UBA region}

A Neoarchean magmatic event is confirmed by the occurrence of the alkaline granitic gneisses of Serra do Eixo that emplaced $2693 \pm 5 \mathrm{Ma}$ ago. This age is similar to that recently obtained for the syenites and syeno-granites of the Caraguataí Massif (Table 1; Cruz

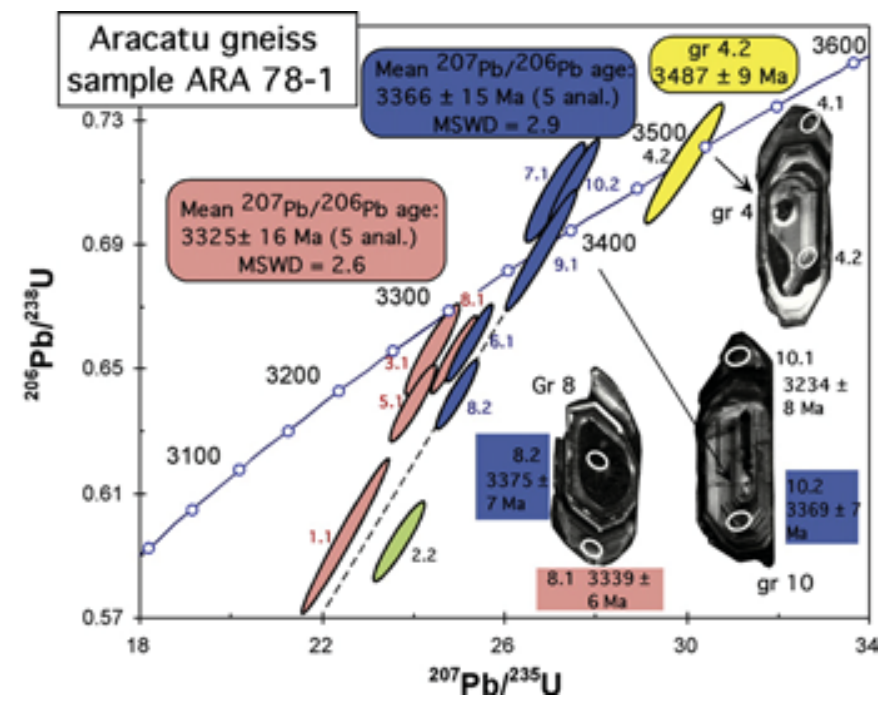

Fig. 5. Concordia diagram with cathodo-luminescence (CL) images for magmatic zircons of a trondhjemitic gneiss from the Aracatu Massif (sample ARA78-1). SHRIMP analyses and error ellipses are reported at $1 \sigma$. The spot size reported is around $30 \mu \mathrm{m}$.
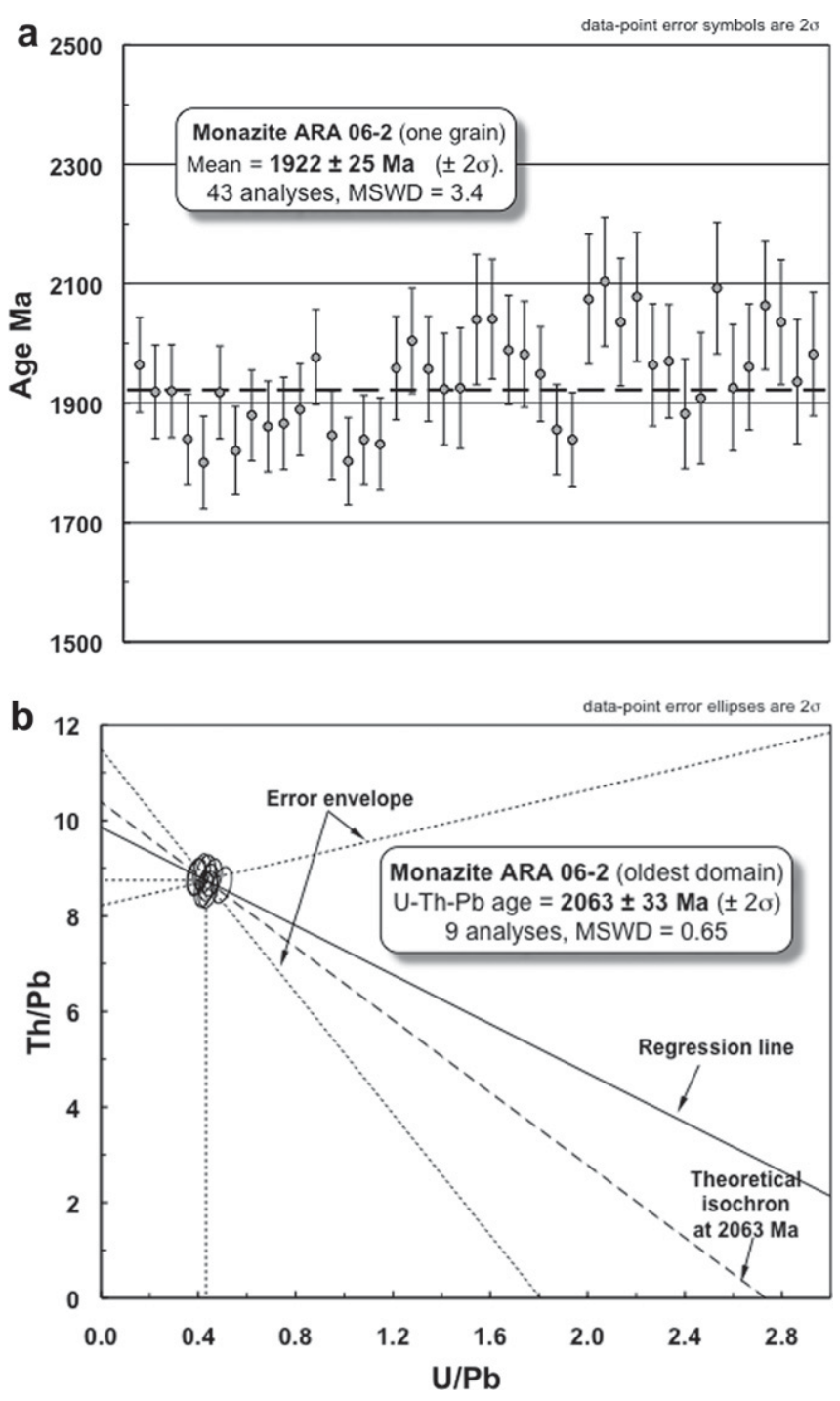

Fig. 6. a Weighted average age calculated using the EPMA technique applied to one single monazite grain from the ARA 06-2 gneiss sample. b isochron plot of $\mathrm{Th} / \mathrm{Pb}$ $\mathrm{vs}$. $\mathrm{U} / \mathrm{Pb}$ for the oldest domain of the monazite grain from the ARA6-2 gneiss sample.

et al., 2012), $60 \mathrm{~km}$ to the north of the UBA region, in the Chapada Diamantina (Fig. 2). It is also in the same age range as that obtained for the Pé de Serra granitic to syenitic pluton (U-Pb SHRIMP age of $2652 \pm 11 \mathrm{Ma}$; Marinho et al., 2008) in the eastern part of the Contendas-Mirante belt, (Fig. 2). At $2.7 \mathrm{Ga}$, the Eixo gneisses had a $\varepsilon_{N d t}$ value ca -3 , whereas it ranges between -4 and -6 in the Caraguataí syenite (Cruz et al., 2012). These negative $\varepsilon_{N d t}$ values and the corresponding model age (3.28 Ga, Table 1 ) indicate that the ca 2.7 Ga alkaline magmatism is primarily the result of crustal reworking processes from the surrounding Paleoarchean gneisses. Furthermore, the felsic volcanics that emplaced $2.74 \mathrm{Ga}$ ago in the Umburanas greenstone belt (Table 1) are characterized by $\varepsilon_{N d t}=-4$, which is in agreement with a crustal input. However, another sample from the same volcanics has a $\varepsilon_{N d t}$ value equal to +1.5 , which also suggests some juvenile input from a depleted mantle ca 2.7 Ga (Bastos Leal et al., 2003).

\subsection{What is the age of the proto-crust in the Gavião block?}

The occurrence of inherited zircon grains with ages up to $3.5 \mathrm{Ga}$ indicates the existence of an old continental crust that was 


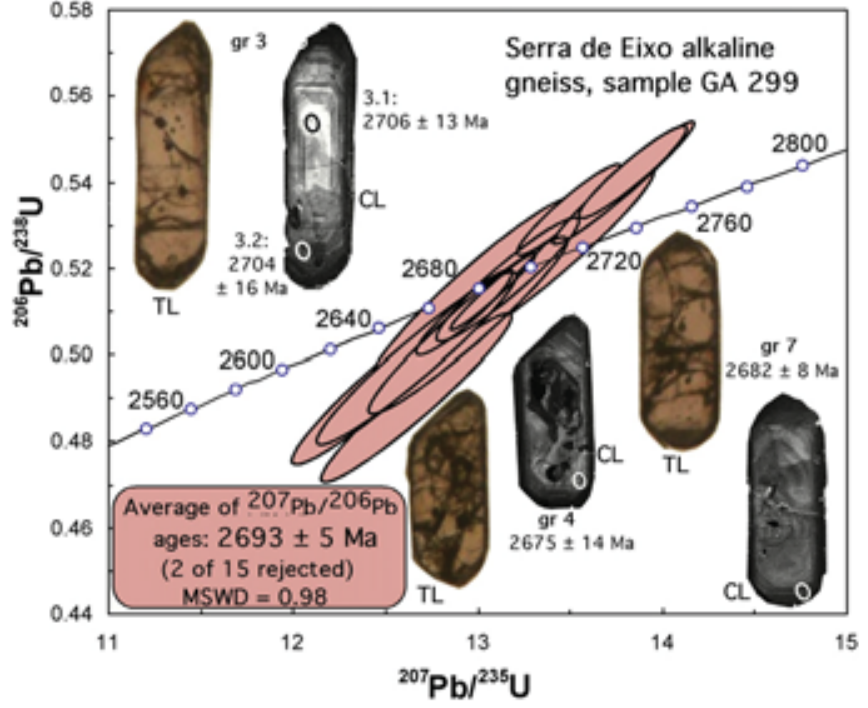

Fig. 7. Concordia diagram 0 with cathodo-luminescence (CL) and transmitted light (TL) images for magmatic zircons of an alkaline gneiss from the Serra de Eixo Massif (sample GA 299). SHRIMP analyses and error ellipses are reported at $1 \sigma$. The spot size reported is around $30 \mu \mathrm{m}$.

probably totally destroyed and recycled during the main Paleoarchean events that took place between 3.3 and $3.4 \mathrm{Ga}$. The Nd isotopes also provide further evidence of the recycling of an older proto-crust. Fig. 11 reports the $\varepsilon_{N d t}$ values for the Archean rocks versus their zircon ages. Most of these rocks have negative $\varepsilon_{N \mathrm{dt}}$ values, suggesting that they either had a significant crustal residence time before their formation or they incorporated an older crustal component. The Nd model ages (Table 1) range between 3.3 and 3.7 Ga in the UBA region (Santos Pinto, 1996), 3.5 and 3.7 Ga in the Sete Voltas gneisses (Martin et al., 1997) and 3.3 and 3.7 Ga in the Brumado-Caculé-Caetité region (Bastos Leal et al., 1998).

On the other hand, it should be noted that the model age (3.27 Ga; Table 1) obtained for the Bernada gneisses (No. 2 in Fig. 11) is slightly younger than its zircon age (3.39 Ga). In order to

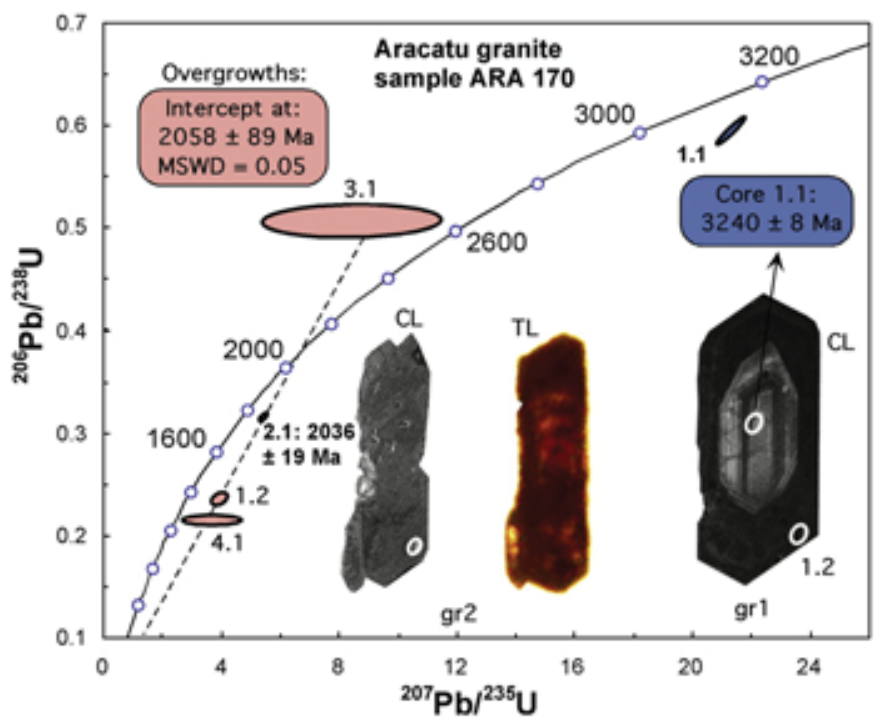

Fig. 8. Concordia diagram with cathodo-luminescence $(\mathrm{CL})$ and transmitted light $(\mathrm{TL})$ images for magmatic zircon grains from a peraluminous granite of the Aracatu Massif (sample ARA 170). SHRIMP analyses and error ellipses are reported at $1 \sigma$. The spot size reported is ca $30 \mu \mathrm{m}$.

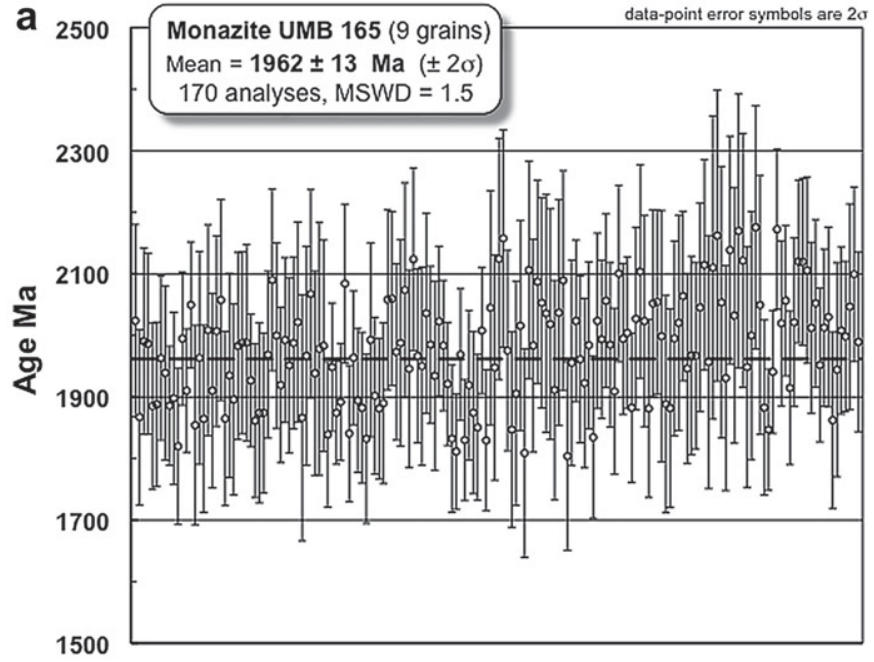

b

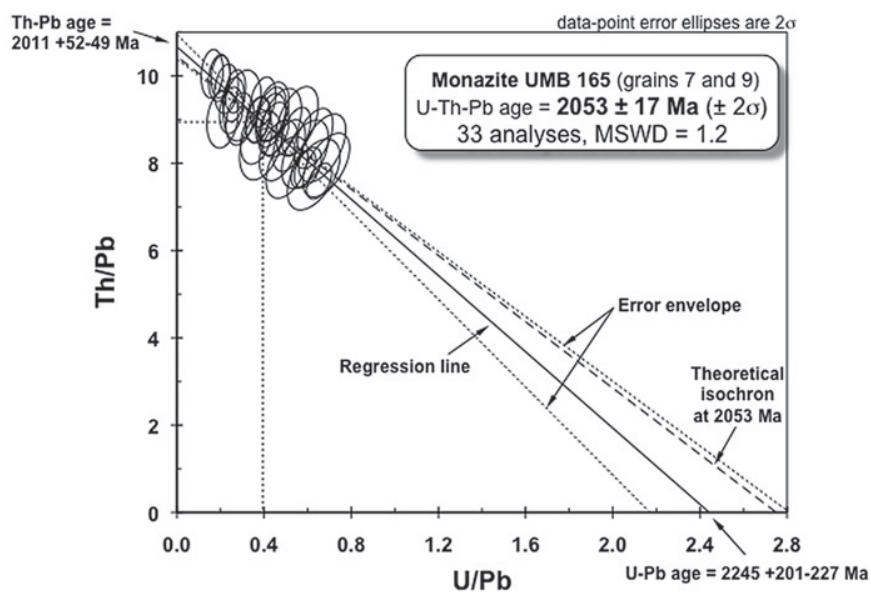

Fig. 9. a Weighted average age calculated using the EPMA technique applied to nine monazite grains from the Umburanas granite (sample UMB 165). b Isochron plot of $\mathrm{Th} / \mathrm{Pb}$ vs. U/Pb (EPMA) for grains 7 and 9 from sample UMB 165.

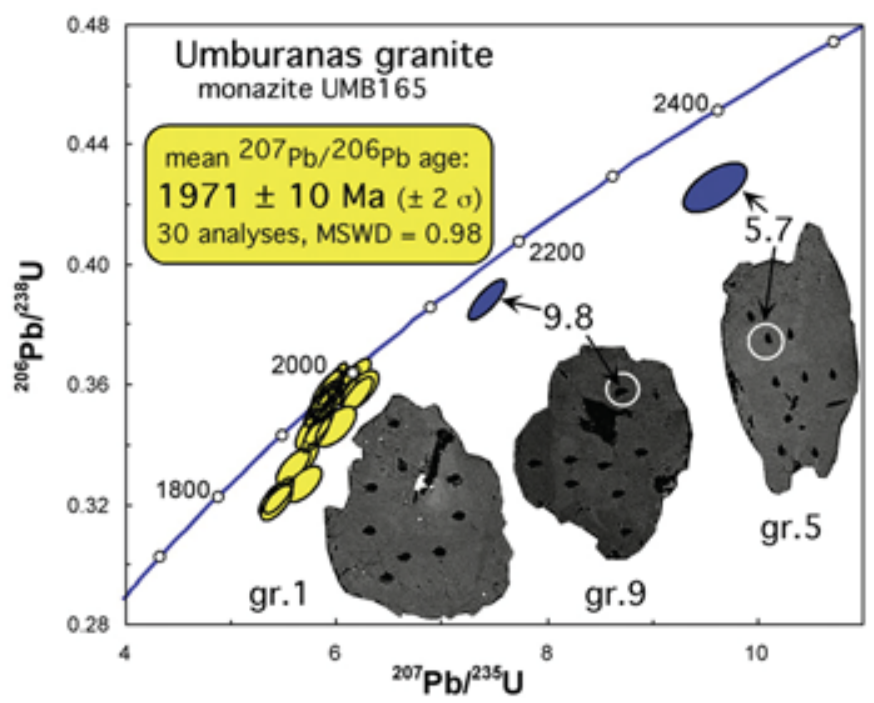

Fig. 10. Concordia diagram with back-scattered images for monazite grains from the Umburanas granite (sample UMB 165). LA-ICPMS analyses and error ellipses are reported at $1 \sigma$. The spot size reported is $7 \mu \mathrm{m}$. 
Table 4

Summary of the monazite LA-ICPMS data.

\begin{tabular}{|c|c|c|c|c|c|c|c|c|c|c|c|c|c|c|}
\hline \multirow[t]{2}{*}{ Grain spot } & \multirow[t]{2}{*}{$\mathrm{U}(\mathrm{ppm})$} & \multirow[t]{2}{*}{ Th (ppm) } & \multirow[t]{2}{*}{$\mathrm{U} / \mathrm{Th}$} & \multirow[t]{2}{*}{$\mathrm{Pb}(\mathrm{ppm})$} & \multicolumn{4}{|c|}{ Radiogenic ratios } & \multirow[t]{2}{*}{$\rho$} & \multicolumn{4}{|l|}{ Age (Ma) } & \multirow[t]{2}{*}{ Conc. $\%$} \\
\hline & & & & & ${ }^{207} \mathrm{~Pb} /{ }^{235} \mathrm{U}$ & $\pm 1 \sigma$ & ${ }^{206} \mathrm{~Pb} /{ }^{238} \mathrm{U}$ & $\pm 1 \sigma$ & & ${ }^{206} \mathrm{~Pb} /{ }^{238} \mathrm{U}$ & $\pm 1 \sigma$ & ${ }^{207} \mathrm{~Pb} /{ }^{206} \mathrm{~Pb}$ & $\pm 1 \sigma$ & \\
\hline 1.1 & 58294 & 874 & 67 & 4211 & 5.429 & 0.088 & 0.3236 & 0.0037 & 0.71 & 1807 & 18 & 1981 & 28 & 91 \\
\hline 1.2 & 51689 & 1050 & 49 & 4995 & 5.835 & 0.089 & 0.3468 & 0.0039 & 0.74 & 1920 & 19 & 1986 & 26 & 97 \\
\hline 1.3 & 67417 & 1188 & 57 & 6033 & 5.386 & 0.084 & 0.3227 & 0.0037 & 0.73 & 1803 & 18 & 1972 & 27 & 91 \\
\hline 1.4 & 55110 & 1182 & 47 & 5328 & 5.798 & 0.090 & 0.3441 & 0.0039 & 0.73 & 1906 & 19 & 1989 & 27 & 96 \\
\hline 1.5 & 47353 & 626 & 76 & 4534 & 5.845 & 0.097 & 0.3528 & 0.0041 & 0.70 & 1948 & 19 & 1959 & 29 & 99 \\
\hline 1.6 & 47978 & 601 & 80 & 4663 & 5.932 & 0.099 & 0.3546 & 0.0041 & 0.69 & 1957 & 19 & 1977 & 29 & 99 \\
\hline 1.7 & 47557 & 551 & 86 & 4444 & 5.916 & 0.104 & 0.3554 & 0.0042 & 0.67 & 1960 & 20 & 1968 & 30 & 100 \\
\hline 1.8 & 53322 & 649 & 82 & 5071 & 5.836 & 0.101 & 0.3529 & 0.0041 & 0.67 & 1948 & 20 & 1956 & 30 & 100 \\
\hline 5.1 & 48016 & 629 & 76 & 3936 & 5.429 & 0.101 & 0.3214 & 0.0038 & 0.64 & 1796 & 19 & 1994 & 32 & 90 \\
\hline 5.2 & 40670 & 696 & 58 & 3733 & 5.578 & 0.102 & 0.3334 & 0.0039 & 0.64 & 1855 & 19 & 1976 & 31 & 94 \\
\hline 5.3 & 42889 & 529 & 81 & 4066 & 5.914 & 0.112 & 0.3554 & 0.0042 & 0.63 & 1960 & 20 & 1967 & 33 & 100 \\
\hline 5.4 & 45624 & 677 & 67 & 4295 & 5.751 & 0.108 & 0.3455 & 0.0041 & 0.63 & 1913 & 20 & 1967 & 32 & 97 \\
\hline 5.5 & 64647 & 445 & 145 & 5419 & 5.976 & 0.124 & 0.3465 & 0.0043 & 0.59 & 1918 & 20 & 2030 & 36 & 94 \\
\hline 5.6 & 55636 & 470 & 118 & 5141 & 6.200 & 0.124 & 0.3586 & 0.0043 & 0.60 & 1976 & 21 & 2035 & 34 & 97 \\
\hline 5.7 & 59316 & 259 & 229 & 4662 & 9.591 & 0.203 & 0.4256 & 0.0053 & 0.59 & 2286 & 24 & 2492 & 35 & 92 \\
\hline 5.8 & 58694 & 862 & 68 & 4589 & 5.670 & 0.122 & 0.3273 & 0.0041 & 0.58 & 1825 & 20 & 2038 & 37 & 90 \\
\hline 7.1 & 20368 & 699 & 29 & 2046 & 5.797 & 0.083 & 0.3529 & 0.0040 & 0.78 & 1948 & 19 & 1944 & 25 & 100 \\
\hline 7.2 & 21180 & 697 & 30 & 2152 & 5.804 & 0.083 & 0.3529 & 0.0040 & 0.78 & 1948 & 19 & 1946 & 25 & 100 \\
\hline 7.3 & 24232 & 658 & 37 & 2421 & 5.857 & 0.085 & 0.3552 & 0.0040 & 0.77 & 1959 & 19 & 1951 & 25 & 100 \\
\hline 7.4 & 17418 & 332 & 52 & 1699 & 6.186 & 0.097 & 0.3572 & 0.0041 & 0.74 & 1969 & 19 & 2038 & 27 & 97 \\
\hline 7.5 & 19565 & 504 & 39 & 1996 & 5.900 & 0.097 & 0.3584 & 0.0042 & 0.71 & 1975 & 20 & 1948 & 29 & 101 \\
\hline 7.6 & 21909 & 714 & 31 & 2244 & 5.903 & 0.089 & 0.3553 & 0.0040 & 0.75 & 1960 & 19 & 1964 & 26 & 100 \\
\hline 7.7 & 22040 & 909 & 24 & 2346 & 5.918 & 0.086 & 0.3596 & 0.0040 & 0.77 & 1980 & 19 & 1947 & 25 & 102 \\
\hline 7.8 & 26715 & 795 & 34 & 2562 & 5.674 & 0.089 & 0.3350 & 0.0038 & 0.73 & 1863 & 19 & 1999 & 27 & 93 \\
\hline 9.1 & 30358 & 2668 & 11 & 3655 & 5.956 & 0.088 & 0.3611 & 0.0042 & 0.78 & 1987 & 20 & 1941 & 25 & 102 \\
\hline 9.2 & 30844 & 755 & 41 & 3167 & 6.066 & 0.095 & 0.3601 & 0.0043 & 0.75 & 1983 & 20 & 1979 & 26 & 100 \\
\hline 9.3 & 40588 & 890 & 46 & 4013 & 5.884 & 0.091 & 0.3558 & 0.0042 & 0.76 & 1962 & 20 & 1946 & 26 & 101 \\
\hline 9.4 & 30839 & 717 & 43 & 3160 & 5.889 & 0.094 & 0.3586 & 0.0042 & 0.74 & 1976 & 20 & 1934 & 27 & 102 \\
\hline 9.5 & 30675 & 2656 & 12 & 3730 & 6.022 & 0.089 & 0.3605 & 0.0042 & 0.78 & 1984 & 20 & 1965 & 25 & 101 \\
\hline 9.6 & 36273 & 737 & 49 & 3606 & 6.144 & 0.099 & 0.3624 & 0.0043 & 0.74 & 1994 & 20 & 1991 & 27 & 100 \\
\hline 9.7 & 36033 & 775 & 47 & 3534 & 5.893 & 0.098 & 0.3556 & 0.0043 & 0.72 & 1961 & 20 & 1951 & 29 & 101 \\
\hline 9.8 & 30771 & 898 & 34 & 3347 & 7.417 & 0.113 & 0.3885 & 0.0045 & 0.77 & 2116 & 21 & 2200 & 25 & 96 \\
\hline
\end{tabular}

obtain a model age that is equal to the zircon age, we need to use a more depleted mantle at $3.39 \mathrm{Ga}$ with a present-day ${ }^{143} \mathrm{Nd} /{ }^{144} \mathrm{Nd}$ ratio of $=0.513235$ (epsilon zero value of +11.6 ). Using this mantle as a model for the other gneisses, the set of model ages becomes older by ca $100 \mathrm{Ma}$, ranging between 3.4 and $3.8 \mathrm{Ga}$. Consequently, the existence of a crust older than $3.4 \mathrm{Ga}$ is also shown by the $\mathrm{Nd}$

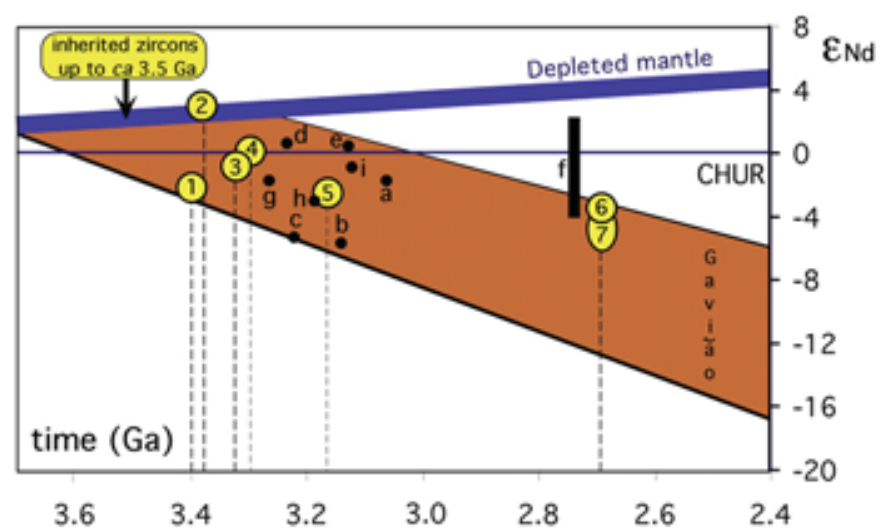

Fig. 11. Nd vs. time isotopic evolution diagram for the gneisses from the Gavião Block, which are dated using $\mathrm{U}-\mathrm{Pb}$ zircon techniques (references in Table 1). SHRIMP (1-6) and LA-ICPMS (7) ages = large yellow circles: 1- Sete Votas $3.4 \mathrm{Ga}$ gneiss, 2- Bernada 3.4 Ga gneiss, 3- Aracatu 3.3 Ga gneiss, 4- Mundo Novo $3.3 \mathrm{Ga}$ meta-dacite, 5-Sete Voltas/Lagoa do Morrro 3.2 Ga gneisses, 6- Serra de Eixo $2.7 \mathrm{Ga}$ alkaline gneisses. 7- Caraguataí 2.7 Ga meta-syenite. TIMS evaporation (minimum) ages = small black circles: a- Mairi 3.0 Ga gneiss, b- Sete Voltas $3.2 \mathrm{Ga}$ gneiss, c- Aracatu 3.2 Ga gneiss, d- Mariana 3.3 Ga gneiss, e- Serra de Eixo 3.2 Ga gneiss, f- Umburanas dacite, g- Lagoa Macambira 3.3 Ga gneiss, h- Lagoa Macambira 3.2 Ga gneiss, i- Lagoa Macambira 3.1 Ga granite. The error envelope is reported for the dated gneisses and felsic volcanics in the Gavião block (references in Table 1). isotopes and we cannot rule out finding zircon xenocrysts or detrital zircon grains, or even rocks, giving ages of $3.6 \mathrm{Ga}$ as in the Serrinha block (Rios et al., 2008) or up to $3.8 \mathrm{Ga}$, as recorded in detrital zircon grains from sediments of the Quadrilátero Ferrifero region, in the southern São Francisco Craton (Hartmann et al., 2006).

\subsection{Paleoproterozoic metamorphism and the related magmatism}

A ca $2.0 \mathrm{Ga}$ event is recorded by the monazite (EPMA ages ranging from $1922 \pm 25$ to $2063 \pm 33 \mathrm{Ma}$ ) in the $3.33 \mathrm{Ga}$ Aracatu gneisses. They indicate that a high temperature metamorphism, reaching migmatization, affected the Archean rocks during the Paleoproterozoic. A related magmatic event is shown by the SHRIMP zircon age obtained for the Aracatu granite; even if it is imprecise $(2053 \pm 65 \mathrm{Ma})$, it is still within the range of the monazite ages. The occurrence of an Archean core (ca $3.25 \mathrm{Ga}$ ) in one zircon is in agreement with the Nd model ages for all the peraluminous granites (3.10-3.77 Ga; Table 1) and shows that these granites result from the partial melting of the Archean surrounding gneissic basement. The La-ICPMS monazite age obtained for the Umburanas granite at $1971 \pm 10$ Ma must also be related to the ca $2.0 \mathrm{Ga}$ crustal melting event obtained on similar granites (Santos Pinto et al., 1998; Bastos Leal et al., 2000).

\subsection{Occurrences of paleoarchean relicts in the South America cratons and in Western Africa}

Before the opening of the South Atlantic Ocean, South America and Africa constituted a single continental mass. The Amazonian Craton was connected with the West Africa Craton and the São Francisco Craton was connected with the Congo Craton (ref. below). 
Relicts of Paleoarchean terranes remain extremely scarce in these cratons, as it will be noticed and discussed here. A general figure showing the location of the main cratons in South America can be found in Hartmann et al. (2001). Cordani (2003) provides a similar figure showing the relationship with the Congo Craton.

In the northern part of South America, the high-grade terranes of Imataca in Venezuela recorded main crustal stages ca 2.7-3.0 Ga and up to $3.2 \mathrm{Ga}$ (Tassinari et al., 2004). Until now, the pioneer work of Montgomery and Hurley (1978), with ages ca 3.4-3.7 Ga, has not been confirmed. Archean rocks are also described in the central Amazonian province, in the Carajás region and south of the Amapá region (Brazil). The main stages of crustal growth are ca 2.9-3.0 Ga and 3.2-3.3 Ga, respectively, based on zircon ages and $\mathrm{Nd}$ isotopes (Althoff et al., 2004; Rosa-Costa et al., 2006; Oliveira et al., 2009; Almeida et al., 2011 and references therein). Detrital zircon grains from a quartzite provided SHRIMP ages up to 3.4-3.7 Ga, which indicate the existence of Paleoarchean rocks in the Carajás province (Macambira et al., 1998). SHRIMP ages up to 3.4-3.5 Ga (Rino et al., 2003), obtained for zircon grains from sands collected at the mouth of the Amazon River, also constrain the occurrence of Paleoarchean rocks in the Amazonian Craton.

The West Africa Craton is related to the Amazonian Craton in geodynamical reconstructions (i.e. Cordani, 2003; Cordani and Teixeira, 2007 and references their in). It also contains Paleoarchean relicts as in the Reguibat Rise (Mauritania). SHRIMP zircon ages of orthogneisses are ca 3.5-3.6 Ga (Potrel et al., 1996) and the main crust was formed ca 2.9-3.2 Ga (Chardon, 1996; Potrel et al., 1998; Key et al., 2008). In the Man Rise (Guinea), tonalitic gneisses and granulitic gabbros ca 3.5-3.6 Ga are also described (SHRIMP zircon ages in Thiéblemont et al., 2001; Barth et al., 2002). The main crust was developed ca 2.8-3.3 Ga (Kouamelan et al., 1997) in the Ivory Coast. Between the West Africa Craton and the Congo Craton, the Benin-Nigeria shield, which corresponds to the Pan-African mobile belt, also contains relicts of Paleoarchean age (Kudan gneisses ca $3.57 \mathrm{Ga}$; Kröner et al., 2001).

In Brazil, Archean relicts were also recognized in the São José do Campestre massif located to the north of the São Francisco Craton, in the Borborema Province close to the city of Natal (Fig. 1). Relicts of tonalitic gneisses exhibit the oldest zircon ages between 3.4 and 3.5 Ga with Nd $\mathrm{T}_{\mathrm{DM}}$ ages $>3.7 \mathrm{Ga}$ (Dantas et al., 2004). Other felsic gneisses, including reworked and juvenile crusts, are 3.0-3.3 Ga old. Late Archean syeno-granites are emplaced at around $2.7 \mathrm{Ga}$. These rocks are also involved in Paleoproterozoic accretionary orogenic processes ca 2.2-2.0 Ga. This sequence of ages is rather similar to the sequence recognized in the Gavião block and our results reinforce the correlation suggested by Dantas et al. (2004) between the São José do Campestre Massif and the São Francisco Craton. In the São Fancisco Craton, the oldest Paleoarchean gneisses and relicts are between 3.4 and $3.8 \mathrm{Ga}$, as detailed above in this article. In Uruguay, the Rio de la Plata Craton contains Paleoarchean relicts with a zircon age for a metatonalite ca $3.41 \mathrm{Ga}$ in the Nico Perez terrane (Hartmann et al., 2001). In Argentina, a xenocryst of zircon, also dated at ca $3.41 \mathrm{Ga}$, was found in the Patagonian batholith (Rolando et al., 2002).

The Congo Craton is generally correlated to the São Francisco Craton because of: (1) the direct connection between the cratons when the South Atlantic Ocean was re-closed, and (2) similarities between their Archean and Paleoproterozoic evolutions. Several papers have already discussed this correlation (i.e. Alkmim et al. 2006; De Waele et al., 2008; Cordani et al., 2009). Juvenile magmatism occurred ca 2.9-3.0 Ga in the NW part of the Congo Craton (Toteu et al., 2001; Pouclet et al., 2007; Tchameni et al., 2010). A large alkaline crustal magmatism, derived from the partial melting of surrounding TTG suites, developed ca $2.7 \mathrm{Ga}$ and exhibits model ages between 2.9 and 3.4 Ga (Tchameni et al., 2000; Shang et al.,
2010); it reinforces the similarities between the two cratons. In the central part of the Congo Craton, the oldest zircon grains from sands of rivers (Batumike et al., 2009) indicate Archean ages ca 2.52.9-3.2 Ga, with the oldest age at 3.6 Ga. According to Barbosa and Sabate (2004), the Archean Gavião block (Brazil) and the Chaillu Massif in the NW Congo Craton occupy symmetric and analogous positions in the accretionary build-up, both acting as uplifted crustal segments producing the Paleoproterozoic JacobinaContendas and Francevillian Basins, which are also in symmetric positions. Moreover, the subduction of the continental crust led to the crustal thickening of both Paleoproterozoic and Archean units ca 2.1-2.0 Ga in the São Francisco and in NW Congo cratons.

\section{Conclusion}

The geological history of the Gavião block started by significant juvenile magmatism emplaced ca $3.4 \mathrm{Ga}$. This magmatism could be purely juvenile (Bernada gneisses) or could incorporate variable amounts of older crustal materials (Sete Voltas old gneisses), which provides evidence for the occurrence of a proto-crust $(\geq 3.5 \mathrm{Ga}$ ). While emplaced and stabilized, this crust began to be actively recycled either directly or through the sedimentary cycle. Such reworking events could have taken place between 3.3 and $3.2 \mathrm{Ga}$ ago (Aracatu gneisses \& Sete Voltas young gneisses) and during the Neoarchean ( 2.7 Ga, Serra do Eixo \& Caraguataí alkaline gneisses). The Paleoproterozoic melting of the Archean crust is probably related to the major crustal thickening process following the ca 2.1 Ga collision on the eastern side of the Gavião block with the Jequié granulites.

Relicts ca 3.4-3.5 Ga or older are exceptional in both the South American Cratons as well as in the Western Africa Archean Cratons. They provide evidence for proto-crusts up to $3.8 \mathrm{Ga}$ old which are often totally destroyed during the main accretional processes observed in the cratons and developed between ca 3.0 and $3.4 \mathrm{Ga}$. The Gavião block in the São Francisco Craton constitutes an important region in terms of the study of early crustal evolution in South America.

\section{Acknowledgments}

Thanks are due to the CAPES-COFECUB project 624/09 which supported the collaboration between UFBA in Brazil and the Universities of Rennes, Clermont-Ferrand and the CNRS in France. Jailma Santos de Souza is thanked for her precious help by drawing Figs. 1 and 2. We are also grateful to Basílio Elesbão da Cruz Filho (CPRM) for georeferencing the geochronological sample points. We thank Dr. S. Mullin who improved the English content of the final version of the paper. We also thank Jaana Halla and an anonymous reviewer for their helpful and constructive comments.

\section{Appendix}

Zircon analyses were performed using the SHRIMP II at Canberra, ANU, Australia, following the methods given in Williams (1998). Uncertainties for the individual analyses (ratios and ages) are given at the $1 \sigma$ level (Table 3 ), but the uncertainties in calculated weighted mean ages (Ludwig, 2003) are reported at $2 \sigma$. Two samples of monazite (EPMA dating) were analyzed using a Cameca SX 50 electron microprobe (BRGM, Orléans, France). The analytical procedure is detailed in Cocherie et al. (1998) and Cocherie and Albarède (2001). U-Th- $\mathrm{Pb}$ geochronology of monazite was conducted by LA-ICPMS at the UMR 6524, Clermont-Ferrand (France). Data are corrected for $\mathrm{U}-\mathrm{Pb}$ fractionation occurring during laser sampling and for instrumental mass discrimination (mass bias) by standard bracketing with repeated measurements of Moacyr 
monazite standard (Seydoux-Guillaume et al., 2004). Ages were generated using the Isoplot/Ex software package by Ludwig (2003). The $\mathrm{U}-\mathrm{Th}-\mathrm{Pb}$ concentrations were calibrated relative to the certified contents of the Moacyr monazite standard. More details are reported in Hurai et al. (2010). The $\mathrm{Nd}$ model ages were calculated using a linear model of depleted mantle from $4.54 \mathrm{Ga}$ with a present-day ${ }^{143} \mathrm{Nd} /{ }^{144} \mathrm{Nd}$ ratio of 0.51315 (epsilon zero value of +10 ) and a ${ }^{147} \mathrm{Sm} /{ }^{144} \mathrm{Nd}$ ratio of 0.2137 (DePaolo, 1988, Table 1 ).

\section{References}

Almeida, J.A.C., Dall'Agnol, R., Oliveira, M.A., Macambira, M.J.B., Pimentel, M.M., Rämo, O.T., Guimarães, F.V., Leite, A.A.S., 2011. Zircon geochronology, geochemistry and origin of the TTG suites of the Rio Maria granite-greenstone terrane: Implications for the growth of the Archean crust of the Carajás province, Brazil. Precambrian Research 187, 201-221.

Alkmim, F.F., Brito Neves, B.B., Castro Alves, J.A., 1993. Arcabouço tectônico do Cráton do São Francisco: uma revisão. In: Dominguez, J.M.L., Misi, A. (Eds.), O Cráton do São Francisco. SBG - Núcleo BA/SE, 45-62.

Alkmim, F.F., Marshak, S., Pedrosa-Soares, A.C., Peres, G.G., Cruz, S.C.P., Whittington, A., 2006. Kinematic evolution of the Araçuai-West Congo orogen in Brazil and Africa: nutcracker tectonics during the Neoproterozoic assembly of Gondwana. Precambrian Research 149, 43-64.

Althoff, F., Barbey, P., Boullier, A.M., 2004. 2.8-3.0 Ga plutonism and deformation in the SE Amazonian craton: the Archaean granitoids of Marajoara (Carajás Mineral Province, Brazil). Precambrian Research 104, 187-206.

Barbosa, J.S.F., Sabaté, P., 2002. Geological Features and the Paleoproterozoic Collision of Four Archaen Crustal Segments of the São Francisco Craton, Bahia, Brazil: A synthesis. Anais da Academia Brasileira de Ciências 74-2. 343-359.

Barbosa, J.S.F., Sabaté, P., 2004. Archaen and Paleoproterozoic crust of the São Francisco Bahia, Brazil: geodynamic features. Precambrian Research 133, 1-27.

Barth, G., Rudnick, R.L., Carlson, R.W., Horn, I., William, F., McDonough, W.F., 2002. $\mathrm{Re}-\mathrm{Os}$ and $\mathrm{U}-\mathrm{Pb}$ geochronological constraints on the eclogite-tonalite connection in the Archean Man Shield, West Africa. Precambrian Research 118, 267-283.

Bastos Leal, L.R., Teixeira, W., Cunha, J.C., Macambira, M.J.B., 1998. Archaean tonalitic-trondhjemitic and granitic plutonism in the Gavião Block, São Francisco Craton, Bahia, Brazil: geochemical and geochronological characteristics. Revista Brasileira de Geociências 28 (2), 209-220.

Bastos Leal, L.R., Teixeira, W., Cunha, J.C., Menezes Leal, A.B., Macambira, M.J.B., Rosa, M.L.S., 2000. Isotopic signatures of Palaeoproterozoic granitoids of the Gavião block and implications for the evolution of the São Francisco craton, Bahia, Brazil. Revista Brasileira de Geociências 30 (1), 66-69.

Bastos Leal, L.R., Cunha, J.C., Cordani, U.G., Teixeira, W., Nutman, A., Menezes Leal, A.B., Macambira, M.J.B., 2003. SHRIMP U-Pb, ${ }^{207} \mathrm{~Pb} / 206 \mathrm{~Pb}$ zircon dating and Nd isotopic signature of the Umburanas greenstone belt, Northern São Francisco Craton, Brazil. Journal of South American Earth Sciences 15, 775-785.

Batumike, J.M., Griffin, W.L., O’Reilly, S.Y., Belousova, E.A., Pawlitschek, M., 2009. Crustal evolution in the central Congo-Kasai Craton, Luebo, D.R. Congo: insights from zircon $\mathrm{U}-\mathrm{Pb}$ ages, Hf-isotope and trace-element data. Precambrian Research 170, 107-115.

Chardon, D., 1996. Les déformations continentales archéennes, exemples naturels et modèlisation thermomécanique. Géosciences Rennes 76, 257.

Cocherie, A., Legendre, O., Peucat, J.J., Kouamelan, A.N., 1998. Geochronology of polygenetic monazites constrained by in situ electron microprobe Th-U-total $\mathrm{Pb}$ determination: implications for lead behaviour in monazite. Geochimica et Cosmochimica Acta 62, 2475-2497.

Cocherie, A., Albarède, F., 2001. An improved $\mathrm{U}-\mathrm{Th}-\mathrm{Pb}$ age calculation for electron microprobe dating of monazite. Geochimica et Cosmochimica Acta 65, 4509-4522.

Cordani, U.G., 2003. From Rodinia to Gondwana: a review of the available evidence from South America. Gondwana Research 6 (2), 275-283.

Cordani, U.G., Teixeira, W., 2007. Proterozoic accretionary belts in the Amazonian craton. In: Hatcher, R.D., et al. (Eds.), Framework of Continental Crust. Geological Society of America Memoir, vol. 200, pp. 297-320.

Cordani, U.G., Teixeira, W., Trindade, R.I., 2009. The position of the Amazonian Craton in supercontinents. Gondwana Research 15, 396-407.

Condie, K.C., 1981. Archaean Greenstone Belts. Elsevier, Amsterdam, p. 434.

Cruz, S.C.P., Peucat, J.J., Carneiro, M.A., Teixeira, L., Santos de Souza, J., Barbosa, J.S.F., Leal, A.B.M., Martins, A.A.M., 2012. The Caraguataí syenitic suite, a ca $2.7 \mathrm{Ga}$ alkaline magmatism (petrology, geochemistry and $\mathrm{U}-\mathrm{Pb}$ zircon ages): a Neoarchean crustal melting event in the southern part of the Gavião block (São Francisco Craton), Brazil. Journal of South American Earth Sciences 37, 95-112.

Cunha, J.C., Fróes, R.J.B., 1994. Komatiitos com textura spinifex do Greenstone belt de Umburanas, Bahia. In: Série Arquivos Abertos, vol. 7. CBPM, Salvador, p. 29.

Dantas, E.L, Van Schmus, W.R., Hackspacher, P.C., Fetter, A.H., de Brito Neves, B.B. Cordani, U., Nutman, A.P., Williams, I.S., 2004. The 3.4-3.5 Ga SÑo Jos» do Campestre massif, NE Brazil: remnants of the oldest crust in South America. Precambrian Research 130, 113-137.

Dantas, E.L., Brito-Neves, B.B., Fuck, R.A., 2010. Looking for the oldest rocks of South America: Paleoarchean orthogneiss of the Sobradinho Block, northernmost foreland of the São Francisco Craton, Petrolina, Pernambuco, Brazil. VII SSAGI South American Symposium on Isotope Geology, Brasília, 137-140.
Delgado, I.M., Souza, J.D., Silva, L.C., Filho, N.C.S., Santos, R.A., Pedreira, A.J., GuimarÑes, J.T., Angelim, L.A.A., Vasconcelos, A.M., Gomes, I.P., Filho, J.V.L., Valente, C.R. Perrotta, M.M., Heineck, C.A. 2003. Geotectônica do Escudo Atlântico, geotectonics of the Atlantic shield. In: Bizzi, L.A., Schobbenhaus, C., Vidotti, R.M.J., Gonçalves, H. (Eds.), Geologia, Tectônica e Recursos Minerais do Brasil. CPRM Brasília, vol. 5, pp. 227-334.

DePaolo, D.J., 1988. Neodymium Isotope Geochemistry, An Introduction. SpringerVerlag, Berlin, p. 187.

De Waele, B., Johnson, S.P., Pisarevsky, S.A., 2008. Palaeoproterozoic to neoproterozoic growth and evolution of the eastern Congo Craton: its role in the Rodinia puzzle. Precambrian Research 160, 127-141.

Hartmann, L.A., Campal, N., Santos, J.O.S., McNaughton, N.J., Bossi, J., Schipilov, A., Lafon, J.M., 2001. Archean crust in the Rio de la Plata Craton, Uruguay, SHRIMP $\mathrm{U}-\mathrm{Pb}$ zircon reconnaissance geochronology. Journal of South American Earth Sciences 14, 557-570

Hartmann, L.A., Endo, I., Suita, M.T.F., Santos, J.O.S., Frantz, J.C., Carneiro, M.A., McNaughton, N.J., Barley, M.E., 2006. Provenance and age delimitation of Quadrilatero Ferrifero sandstones based on zircon $\mathrm{U}-\mathrm{Pb}$ isotopes. Journal of South American Earth Sciences 20, 273-285.

Hurai, V., Paquette, J.L., Huraiová, M., Konečný, P., 2010. Age of deep crustal magmatic chambers in the intra-Carpathian back-arc basin inferred from LAICPMS $\mathrm{U}-\mathrm{Th}-\mathrm{Pb}$ dating of zircon and monazite from igneous xenoliths in alkali basalts. Journal of Volcanology and Geothermal Research 198, 275-287.

Key, R.M., Loughlin, S.C., Gillespie, M., Del Rio, M., Horstwood, M.S.A., Crowley, Q.G., Darbyshire, D.P.F., Pitfield, P.E.J., Henney, P.J., 2008. Two Mesoarchaean Terranes in the Reguibat Shield of NW Mauritania. In: Geological Society, London, Special Publications, vol. 297, 33-52.

Kouamelan, A.N., Delor, C., Peucat, J.J., 1997. Geochronological evidence for reworking of Archean terrains during the Early Proterozoic (2.1 Ga) in the western Côte d'Ivoire (Man Rise-West African Craton). Precambrian Research 86, 177-199.

Kröner, A., Ekwueme, B., Pidgeon, R., 2001. The oldest rocks in West Africa: SHRIMP zircon age for early Archean migmatitic orthogneiss at Kaduna, northern Nigeria. Journal of Geology 109, 399-406.

Ludwig, K.R., 2003. ISOPLOT/EX, Version 3. A Geochronological Toolkit for Microsoft Excel. Berkeley Geochronology Center, Special Publication 4, p. 70.

Macambira, M.J.B., Lafon, J.M., Pidgeon, R.T., 1998. Crescimento crustal Arqueano registrado em zircões de sedimentos da região de Rio Maria, província Carajás, Pará. In: XL Congresso Brasileiro de Geologia. Anais, Belo Horizonte, p. 55.

Marinho, M.M., 1991. La séquence volcano-sédimentaire de Contendas-Mirante et la bordure occidentale du Bloc de Jequié (Craton du São Francisco, Brésil): Un exemple de transition Archéen-Protérozoïque, Ph.D. thesis, University of Clermont-Ferrand, France, $388 \mathrm{p}$

Marinho, M.M., Vidal, P., Alibert, C., Barbosa, J.S.F., Sabaté, P., 1994. Geochronology of the Jequié-Itabuna granulitic belt and the Contendas Mirante volcanosedimentary belt. In: Figueirêdo, M.C.H., Pedreira, A.J. (Eds.), Petrological and Geochronologic Evolution of the Oldest Segments of the São Francisco Craton, vol. 17. Boletim IG-USP, Brazil, 73-96.

Marinho, M.M., Rios, D.C., Conceição, H., Rosa, M.L.S., 2008. Magmatismo alcalino neoarqueano no Craton do São Francisco, Bahia: Pluton Pé de Serra. In: Congresso Brasileiro Geologia, vol. 44. Anais, 597 p.

Martin, H., Sabaté, P., Peucat, J.J., Cunha, J.C., 1991. Un segment de croûte continentale d'âge archéen ancien (3,4 milliards d'années): le massif de Sete Voltas (Bahia, Brésil), vol. 313. Comptes Rendus de l'Académie des Sciences, Paris. 531-538.

Martin, H., Peucat, J.J., Sabaté, P., Cunha, J.C., 1997. Crustal evolution in the Early Archaean of South America: example of the Sete Voltas massif, Bahia State, Brazil. Precambrian Research 82, 35-62.

Mascarenhas, J.F., Silva, E.F.A., 1994. Greenstone Belt de Mundo Novo (Bahia): Caracterização e implicações metalogenéticas no Cráton do São Francisco. CBPM, Salvador, Special Publication, p. 32.

Montgomery, C.W., Hurley, P.M., 1978. Total rock U-Pb and $\mathrm{Rb}-\mathrm{Sr}$ systematics in Imataca series, Guyana shield, Venezuela. Earth Planetary Science Letters 39, 281-290.

Mougeot, R., 1996. Etude de la limite Archéen-Protérozoïque et des minéralisations $\mathrm{Au}, \pm \mathrm{U}$ associées. Exemples de la région de Jacobina (Etat de Bahia, Brésil) et de Carajas (Etat de Para, Brésil). Thèse de l'Université de Montpellier II, 306 p.

Nutman, A.P., Cordani, U.G., 1993. SHRIMP U-Pb zircon geochronology of Archaean granitoids from the Contendas-Mirante area of the Sao Francisco Craton, Bahia, Brazil. Precambrian Research 63, 179-188.

Nutman, A.P., Cordani, U.G., Sabaté, P., 1994. SHRIMP U-Pb ages of detrital zircons from the early Proterozoic Contendas-Mirante supracrustal belt, São Francisco Craton, Bahia, Brazil. Journal of South American Earth Sciences 7 (2), 109-114.

Oliveira, M.A., Dall'Agnol, R., Althoff, F.J., Leite, A.A.S., 2009. Mesoarchean sanukitoid rocks of the Rio Maria Granite-Greenstone Terrane, Amazonian craton, Brazil. Journal of South American Earth Sciences 27, 146-160.

Peucat, J.J., Mascarenhas, J.F., Barbosa, J.S.F., de Souza, S.L., Marinho, M.M., Fanning, C.M., Leite, C.M.M., 2002. 3.3 Ga SHRIMP U-Pb zircon age of a felsic metavolcanic rock from the Mundo Novo Greenstone belt in the São Francisco Craton, Bahia (NE Brazil). Journal of South American Earth Sciences 15, 363-373.

Peucat, J.J., Barbosa, J.S.F., Pinho, I., Paquette, J.L., Martin, H., Fanning, M., Leal, A., Cruz, S., 2011. Geochronology of granulites from the south Itabuna-SalvadorCuraçá Block, São Francisco Craton (Brazil): Nd isotopes and U-Pb zircon ages. Journal of South American Earth Sciences 31, 397-413.

Pouclet, A., Tchameni, R., Mezger, K., Vidal, M., Nsifa, E.N., Shang, C.K., Penaye, J., 2007. Archaean crustal accretion at the northern border of the Congo craton 
(South Cameroon). The charnockite-TTG link. Bulletin de la Société Géologique de France 178, 331-342.

Potrel, A., Peucat, J.J., Fanning, M., Auvray, B., Burg, J.P., Caruba, C., 1996. 3.5 Ga old terranes in the West African Craton, Mauritania. Journal of the Geological Society of London 153, 507-510.

Potrel, A., Peucat, J.J., Fanning, C.M., 1998. Archean crustal evolution of the West African Craton: example of the Amsaga Area (Reguibat Rise). U-Pb and Sm-Nd evidence for crustal growth and recycling. Precambrian Research 90, 107-117.

Pupin, J.P., 1980. Zircon and granite petrology. Contributions to Mineralogy and Petrology 73, 207-220.

Rios, D.C., Davis, D.W., Conceicão, H., Rosa, M.L.S., Davis, W.J., Dickin, A.P., Marinho, M.M., Stern, R., 2008. 3.65-2.10 Ga history of crust formation from zircon geochronology and isotope geochemistry of the Quijingue and Euclides plutons, Serrinha nucleus, Brazil. Precambrian Research 167, 53-70.

Rino, S., Motoki, A., Hirata, T., Maruyama, S., 2003. U-Pb spot dating by LA/ICPMS of single detrital zircon grains collected at the mouth of the Amazon river: continental crustal growth history of the Amazon river basin. Short paper, IV South American Symposium on Isotope Geology, pp. 108-110.

Rolando, A.P., Hartmann, L.A., Santos, J.O.S., Fernandez, R.R., Etcheverry, R.O. Schalamuk, I.A., McNaughton, N.J., 2002. SHRIMP zircon U-Pb evidence for extended Mesozoic magmatism in the Patagonian Batholith and assimilation of Archean components. Journal of South American Earth Sciences 15, 267-283.

Rosa-Costa, L.T., Lafon, J.M., Delor, C., 2006. Zircon geochronology and Sm-Nd isotopic study: further constraints for the Archean and Paleoproterozoic geodynamical evolution of the southeastern Guiana Shield, north of Amazonian Craton, Brazil. Gondwana Research 10, 277-300.

Santos Pinto, M.A., 1996. Le recyclage de la croûte continentale archéenne: exemple du Bloc du Gavião (Bahia - Brésil). Mémoires de Géosciences Rennes 75, 193 p.

Santos Pinto, M.A., Peucat, J.J., Martin, H., Sabaté, P., 1998. Recycling of the Archaean continental crust: the case study of the Gavião Block, Bahia, Brazil. Journal of South American Earth Science 11 (5), 487-498.
Seydoux-Guillaume, A.M., Wirth, R., Deutch, A., Schärer, U., 2004. Microstructure of 24-1928 Ma concordant monazites; implications for geochronology and nuclear waste deposits. Geochemica et Cosmochimica Acta 68, 2517-2527.

Shang, C.K., Liégeois, J., Satir, M., Frisch, W., Nsifa, E.N., 2010. Late Archaean high-K granite geochronology of the northern metacratonic margin of the Archaean Congo craton, Southern Cameroon: evidence for Pb-loss due to nonmetamorphic causes. Gondwana Research 18, 337-355.

Sylvester, P.J., 1989. Post-collisional alkaline granites. Journal of Geology 97, 261-280.

Sylvester, P.J., 1994. Archaean pluton granites. In: Condie, K.C. (Ed.), Archaean Crustal Evolution, 261-364.

Tassinari, C.G., Munha, J.M.U., Teixeira, W., Palacios, T., Nutman, A.P., Sosa, C. Santos, A.P., Calado, B.O., 2004. The Imataca complex, NW Amazonian craton, Venezuela: crustal evolution and integration of geochronological and petrological cooling histories. Episodes 27 (1), 3-11.

Thiéblemont, D., Delor, C., Cocherie, A., Lafon, J.M., Goujou, J.C., Balde, A., Bah, M., Sane, H., Fanning, M.C., 2001. A 3.5 Ga granite-gneiss basement in Guinea: further evidence for early archean accretion within the West African Craton. Precambrian Research 108, 179-194.

Tchameni, R., Lerouge, C., Penaye, J., Cocherie, A., Milesi, J.P., Toteu, S.F., Nsifa, N.E., 2010. Mineralogical constraint for metamorphic conditions in a shear zone affecting the Archean Ngoulemakong tonalite, Congo craton (Southern Cameroon) and retentivity of U-Pb SHRIMP zircon dates. Journal of African Earth Sciences 58, 67-80.

Tchameni, R., Mezger, K., Nsifa, N.E., Pouclet, A., 2000. Neoarchaean crustal evolution in the Congo Craton: evidence from $\mathrm{K}$ rich granitoids of the Ntem complex, southern Cameroon. Journal of African Earth Sciences 30-1, 133-147.

Toteu, S.F., Van Schmus, W.R., Penaye, J., Michard, A., 2001. New U-Pb and Sm-Nd data from north-central Cameroon and its bearing on the pre-Pan African history of central Africa. Precambrian Research 108, 45-73.

Williams, I.S., 1998. U-Th-Pb geochronology by ion probe. In: McKibben, M.A. Shanks, W.C., Ridley, W.I. (Eds.), Applications of Microanalytical Techniques to Understanding Mineralizing Processes. Reviews in Economic Geology, vol. 7, 1-35. 